\title{
The Historical Genesis of the Gadamer/Habermas Controversy
}

\author{
David Ingram \\ University of Northern Iowa
}

Considering the sizable volume of secondary literature on the Gadamer-Habermas debate that has accumulated over the past decade, it may appear to many that little can be added to it in the way of illuminating commentary that has not already been said. This opinion, nevertheless, is disputed by the persistance of the debate itself, which was vigorously renewed in a Canadian symposium (1979).' Moreover, it would appear from perusing Habermas' recent tome, Theorie des koinmunikativen Handelns (1981), that the issues debated in the controversy at least continue to be of vital interest to him. My intention, however, is not to delve into these new materials in order to produce yet another commentary. Nor sliall I unciertake a survey of the secondary literature with the aim of assessing the controversy itself. I propose instead to trace the controversy back to its historical roots in a series of philosophical and sociological debates that throw into relief the neo-Kantian and, above all, the neo-Hegelian motifs that reoccur in the philosophies of the two principals.

The earliest commentaries on the controversy generally underscore the differences between Habermas and Gadamer. Ricoeur's essay, "Ethics and Culture" (1973) is typical in this regard." "Ihough emphasizing the complementarity of Habermas' and Gadamer's views, he was mostly concerned to portray the former as defending a distanciating, explanatory social methodology and the latter as clefending a participatory, hermeneutic one. Along with August Wellmer, Ricceur saw the debate as principally a methodological dispute emanating from antithetical attitudes toward tradition and authority. According to Wellmer, Gadamer's hermeneutics seeks to rehabilitate tradition, prejudice and autlority in a way that reacts against the critical, emancipatory legacy of the Enlightenment appropriated by Habermas in his proposal for a scientifically grounded ideology critique." Subtler comparisons of the two disputants were proffered by Dieter Misgeld and Theodore Kisiel, who attributed their disagreement to a trenchant asymmetry in levels of discourse." On Misgeld's reading of the controversy, Gadamer's position advances an on- 
tological claim about the ineluctable culture-bound nature of understanding that precludes the possibility of attaining a methodologically detached standpoint. Habermas, on the contrary, ustensibly defends the possibility of achieving a methodologically secured, tradition-transcending reflection capable of grounding itself in universal reference points.

The reader attempting to disentangle the often convoluted strands of the first rounds of the controversy will no doubt recognize as true (if only partially) the characterizations of the debate adumbrated above. More recent commentaries by McCarthy, Giddens, Bubner, Ricoeur, Misgeld, Böhler, Kisiel, Mendelsohn, Gall, and How, having had the advantage of being exposed to the later, more conciliatory exchanges, generally emphasize the similarities at least as much as the differences."

It is, I believe, of great consequence that most of these commentators overlook the relationship between this controversy and earlier debates within German sociology and philosophy centering around neo-Kantian schools of thought. This is indeed surprising given the fact that Gadamer and Habermas descend from philosophical traditions steeped in neo-Kantianism--and have even reproached one another for it. Now the theses which I. propose to defend concern Gadamer's and Habermas' respective attempts to break out of this tradition by retrieving aspects of the Hegelian heritage. (It is customary to classify Habermas as the Kantian and Gadamer as the Hegelian, but I shall argue that one can just as easily reverse these classifications.) Eirst., I shall argue that both Gadamer and Habermas repudiate the narrow methodological and positivistic compass of neo-Kantian thought by developing conceptions of practical knowledge that rest upor more basic, dialectical theories of human understanding. The failure of the early commentators to grasp the bilateral nature of this zejection could not but mislead them into interpreting the controversy as if it were a methodological dispute. Second, I intend to show that, not surprisingly, Gadamer and Habermas orient their hermeneutic programs around opposing traditions of Hegelian thought which conceive practical reason in radically different ways. Finally. I shall attempt to defend the thesis that, despite their common rejection of a neo-Kantian fact-value dualism, they nevertheless end up by reaffirming it.

My procedure will be to begin with what I take to be the locus of the controversy. namely Gadamer's and Habermas' respective views concerning the nature of language and society. Rather than cover ground hitherto surveyed by others, I shall iustead collelltrate on a few relatively neglected passages from the corpus of their writings that testify to their salient differences (Sec. I). After laying out the sharpest 
possible contrast between them I shall undertake to show how both philosophers share a common antipathy toward cardinal tenets of neo-Kantian thought. This lengthy historical digression is really the heart of the paper and will be divided into four sections as follows.

The first part (sec. II) attempts to explain how the methodological debates among neo-Kantians at the turn of the century grew out of earlier epistemological disputes dating back to antiquity. The decisive figure in this synopsis is Vico, who marks the transition from the Renaissance preoccupation with rhetoric and poetry to contemporary methodological concerns pertaining to the scientific value of historical understanding. The second part (Sec. III) examines how this latter theme became pivitol for later debates among neo-Kantians. The third part (Sec. IV) addresses two decisive disputes pitting Gadamer and Habermas against representatives of neo-Kantian schools of thought. It is at this juncture of our historical survey that the affinities between Gadamer and Habermas are most evident. The fourth part (Sec. V) analyzes the Hegelian legacy which forms the backbone of their philosophical programs. The conclusion of the essay (Sec. VI) contains some of my own thoughts about the possibility of reconciling Gadamer and Habermas as well as a critical assessment of their attempts to disburden themselves of their neo-Kantian heritage.

The cornerstone of Gadamer's theory of society is a claim about the universality of language as a medium of dialogue. "Language is by itself the game of interpretation that we are all engaged in everyday. In this game nobody is above and before all others; everybody is at the center, is 'it' in this game. Thus it is always his turn to be interpreting." The game metaphor--Gadamer's favorite--is invoked by him to illustrate the primacy of social process over individual agency. Although the individual counts as one voice in the body politic to which the established traditions and institutions must appeal for their own legitimacy. his behavior and power is nonetheless limited by the collective life which binds him to their authority. The resistance of language and tradition to subjective manipulation is directly related to Heidegger's ontological analysis of undexstanding. Finite Dasein is implicated in a lingusstic event over which it has no absolute control. Drawing an analogy between biological and social organism, Gadamer suggests that language is an equilibrium of stratified forces which bears the indelible imprint of its past (qua tradition that has been handed down) and its present, including the infinite richness of nieaning and expression associated with 
a diversified political culture. The diffuseness of communication in Gadamer's organic model of society entails, first, that language is impervious to the kind of hegemonic class domination implicit in a Marxian theory of ideology, and second, that it is a game of near equals and therefore approximately instantiates the sort of reciprocity constitutive of true dialogue. In connection with this general point, Gadamer goes so far as to suggest that even the mass-media technocrat is "educated" by the humble consumer who expresses his power through the scale of preferences he brings to bear in the marketplace.?

In one of his most significant essays, Gadamer warns that external intervention on the part of the social scientist in the life of the community, either in the form of social engineering or social therapy, runs the same risk of upsetting the delicate balance of stratified social forces, which gravitate toward a primary ethical consensus, as do the physicians medical interventions with respect to the physiological homeostasis of the biological organisul. "Therapy intervenes externally into a system that is already internally balanced and self-regulating. Each intervention (Eingriff) which gives rise to a disturbance in this state of equilibrium (Glelchgewicht) runs the danger of unintentionally altering other conditions of equilibrium... we are (here) not concerned with the knowledge of the specialist, who, as the wise man proceeds over and againgt others [den anderen gegenüber tritt], but rather with a type of kruwledge that, however indispensable it may be, cannot be provided by science [and] which alone has its solitary basis in the solidarity that umites everyone." The idea that society, like biological organism, has a range of variation determined by its state of equilibrium entails that ideology critique cannot transgress those boundaries which give society continuity without threatening its collective moral identity.

Gadamer concludes that any attempt to evaluate society on the basis of abstract, transcendental criteria that are external to tradition-bourid understanding inevitably succumbs to utopian extremism and he cites as a case ill point Habermasian psychutherapeutic sociology, which violates conditions of mutual recognition underlying the possibility of communication in general when it arrogates to itself the special privilege of treating others as pathologically affected, and, therefore, as lacking the qualifications for full dialogical parcnership."

Gadaner contends that because de facto traditional authority, including the authority which accrues to the politician, educator, and anyone else who masters the art of producing conviction in others through rhetoric, is a necessary condition for the possibility of generating dialogical consensus, it is ceteris paribus. 
rational. Consistent with this amalgamation of rhetorical humanism and ontological hermeneutics is Gadamer's notion of practical truth. The shared norms governing conduct are neither demonstrable nor univocal, but reflect a plurality of goals and obligations, constantly subject to new and differing interpretations, that emerge naturally in the continuous exchange of opinions and the play of forces representing past and present traditions. One can percelve in Gadamer's appeal to rhetorical humanism, which invests ordinary self-understanding and everyday discourse with the dignity of common sense, a democratic tendency which mitigates the authoritarian aspects of his ontological hermeneutics. According to Gadamer, philosophical hermeneutics must demonstrate the inherent rationality of that understanding and the tradition which grounds it by revealing the deep linguisticality uniting all realms of experience and knowledge.

Habermas attempt to redeem a concept of practical truth takes its bearings from a contrary set of assumptions. Habermas argues that social action exhibits an aetiological profile that is isomorphic to that of neurotically inhibited behavior. Though cultural norms are accepted as legitimate by social agents, they are done so out of ideological compulsions. The repression of authentic emancipatory needs along with the conconitant substitution of publically sanctioned modes of yratification remains incomplete, however, for the former invariably surface in the familiar symptoms of identity crisis--alienation, anomie, and anarchy. Repression is itself a function of subtle economic and political coercion and constitutes an abrogation of dialogical reciprocity. To construe dialogical reciprocity as an ontological condition in the way that Gadamer does "promotes the fiction that Socratic dialogue is possible everywhere and at any time." ${ }^{\circ}$ Given the ubiquitous impact of mass media on our everyday lives, vernacular language and quotidian patterns of speech and thought invariably succumb to the distorting influences of the market. The latter is less a dialogue among equals than it is a rhetorical and strategical manipulation of public opinion by corporate powers and established political elites.

Given the irrationality of actual political discourse, the function of philusophy can only be the advancement of prospective social change through critical enlightenment. Radical critigue presupposes a theoretical standpoint that is at least partially removed from actual political discourse. Herein lies Habermas' deviation from classical humanist thought. Theoretical distanciation is reflected both in critical Theory's return to rranscendental ethics and in its incorporation of the objectifying methods of exact science. Philosophical reflection is not only said to possess the capacity to discover universal criteria of ration- 
ality which warrant the questioning of de facto social consensus but it is also provided with a method--that of psychotherapy--which ostensibly fosters such conduct. Habermas has been especially concerned to show that the criteria of rationality are embedded in the necessary presuppositions for communicative, or consensual, uses of language that ground normative social solidarity. Insofar as persons are held rationally accountable for their actions, they must be imputed to possess the competency to justify their actions in rational discourse. The derining feature of rational persuasion in turn can only be captured in terms of the counter-factual pragnatic conditions underlying an "ideal speech situation" which entail perfect reciprocity, a complete suspension of unilateral economic and political privleges, and freedom from the internal constraints of dogmatic tradition. 12

\section{I}

The methodological disputes among neo-Kantians that form the backdrop to the Gadamer-Habermas controversy have their genesis in the conflict, as Lord Snow so aptly put it. between "two cultures."12 Today this conflict chiefly revolves around the role of scientific method with respect to the research procedures and epistemological criteria of the humanities and social sciences. What is at stake in the conflict is nothing iess than the epistemological credibility of these sciences. Can they be improved by adopting the methods of the exact sciences, or do they provide a form of practical knowledge that resists such regimentation? If they do provide practical knowledge, then how is such knowledge possible?

The above conflict has a long geneology which dates back to ancient Greece. Although Plato did not differentiate kinds of knowledge so much as designate a hierarchy of epistemic levels, he did elevate the abstract, ratiocinative understanding of philosophy and mathematics (episteme) above the concrete, perceptually oriented experience of common sense (doxa). Departing from this premise he quite naturally saw ordinary language and tiadition as confused amalgams of partial truths (doxa) that were easily susceptible to the machinations of sophism. This view ran counter to the classical model of education advanced by the Isocratic school of philosophy, which stressed the importance of rhetoric and puetry for achieving civic virtue. Recalling Pascal's distinction between l'esprit de finesse and 1 'esprit de géométrique, Henri Marrou notes in his study of education in antiquity that whereas Plato reacted against the unregimented, essentially aesthetic ideal of paideia. which promoted the development of human character and inoral sensibility through cultivation in the literary arts, Isocrates, 
who was certainly no practitioner of self-serving sophistry, embraced the ideal. as the highest expression of ethical life. For Plato, the demonstrability and methodological rigor of geometry were the sine gua non of all knowledge, including knowledge of the good. Isocrates, on the contrary, Inaugurated the humanistic tradition that emphasized the importance of emulating the authoritative elocutionary styles of past literati and artfully and innovatively deploying them in service to the community. 13

We owe the first taxonomic treatment of knowledge to Aristotle, who distinguished eplateme (consisting of metaphysics, physics, and mathematics), which he defined as the contemplation of objects that are immune to change of luuman origin, from both phronesis, or practical wisdom, and techne, or productive skill, a schema roughly corresponding to the classical distinction between thēoria, praxis, and poiesis. (Logic was not included in the classification of the sciences, but was instead treated as a propadeutic organon.) By separating these types of discourse, Aristotle succeeded in charting a middle course between Isocrates and Plato. According to Aristotle, phronesis is activity in accordance with the mean (the Greek ideal of sophrōsyne. roughly meaning temporate, or judicious conduct.) which presupposes a kind of grace and artiulness :n applying standards of excellence. Though such standards are capable of discursive, theoretical treatment of the sort found in Aristotle's own work in politics and ethics, their general, practical import must be qualified relative to partjcular circumstances. Significantly, Aristotle identified tradition, not theoria, as the ultimate source of normative enlightenment and he observed that ethical conduct as such is more a function of character and habit than of any technical mastery of rules and means. 14

Aristotle's classification of knowledge was appropriated by the stoics in their simplified triad of logic, physics, and ethics, and this schema was retained mutatis mutandis by medieval scholasticism and its division of the seven liberal arts into the trivium (grammar, dialectic, and rhetoric) and the quadrivium (arithmetic, geometry, astronomy, and music), followed by the more advanced ethical studies in theology, law. and medicine. The scholastics' desire to reconcile reason and faith invariably led them to place an inordinate weight upon dialectic (syllogistic logic) with its overly prolix, abstruse style of Latin, thereby leaving the cultivation of vernacular gramuar and rhetoric in a state of disuetude. The Quattrocento Renaissance humanists such as Loonardo Bruni, Leon Alberti, and Vittorina da Feltre rebelled against the arid metaphysical speculation of the scholastics and sought to infuse the university curriculum with a renewed interest in classical studies. ${ }^{15}$ Theix ideal was 
not so much the contemplative humanism of Petrarch, but the civic humanism espoused earlier by Isocrates.

With the dissolution of the medieval curriculum and the concomitant removal of theology from the realm of knowledge, the natural sciences also rose to a position of prominence. Particularly germane to this development was the discovery of the experimental method, which was given a far-reaching exposition by Erancis Bacon.

The first step of the method as Bacon conceived it was the refutation of those impediments to knowledge which he entitled the "four idols," the principal ones from our perspective being the Idols of the cave and the Idols of the Market Place. Among the former was included the natural propensity to esteem the traditions of the past; the most offensive of the latter was the tendency to reason fallaciously caused by the inherent ambiguity of urdinary language. In Bacon's opinion, the true remedy for these maladies was induction, or the derivation and testing of general axioms vis-à-vis particular matters of fact. 26 The second step of the method involved a massive reclassification of knowledge in which history and poetry (those disciplines subject to the faculties of memory and imagination respectively) were subordinated to pliilosophy, understood as the rational analysis and interpretation of data. In this manner, Bacon not only eliminated theology and metaphysics from the study of nature, but he also extruded moral considerations from the scientific study of ethics and politics. Poetry and history are, ex hypothesi. irrational and, therefore, impractical. Questions of right conduct are relegated to the sphere of divine revelation. The study of ethical and political life is no longer imbued with the normative predilection of classical humanism. but takes on the less edifying task of causal explanation aimed at learning "how to frame and subdue the will or men." 2 "

The identification of philosophy with technological control and manipulation is the chief reason why the experimental method provides "reassurance" (the third step of Bacon's method). Bacon's reconstruction of the sciences, especially his repudiation of the conservative, backward-lcoking ideal of classical humanism, was intended to justify the advance of knowledge through the acquisition of ever more reliable techniques for mastering nature. Bacon's reduction of praxis to techne greatly influenced Thomas Hobbes, who was the first to realize its potential for political science." It was Hobbes, not Machiavelli, who consecrated the first major break with classical humanism by redefining natural law in terms of Galilean mechanics. Both Gadamer and Habermas take cognizance of this decisive turn; while repudiating the metaphysical aspirations of classical political philosophy, they nonetheless sym- 
pathize with the normative treatment, for example, of natural law as it is articulated by Aristotle and the stoics.

Descartes followed Bacon in detaching morality from theory and his endorsement of a mind/body dualism paved the way for a further articulation of scientific method. External nature, including the faculties of sense, memory, and imagination, which Descartes ascribed to the functions of the body, was conceived as res extensa operating under mechanical laws. Mind, which consisted of the sole faculty of reason (res cogitans) was imputed to possess free will. As a nonmaterial thinking substance it was not, as it was for Bacon, transferred to the province of revelation, but was made to function as the metaphysical criterion of knowledge as such. Knowledge was defined both as the acquisition of clear and distinct ideas possessing analytic certitude and the derivation therefrom of compound truths. 19 Despite the fact that Descartes' metaphysics conflicted with the empiricism of Bacon, the mind/body dualism and the theory of ideas found wide acceptance among later British empiricists. Hume, who could discover nothing having legitimate claim to immediate experience save the "given" impressions of sense, used the theory of ideas to extend skepticism to include physics as well as morality.

At the beginning of the eighteenth century the presumption that Newtonian physics offered privileged ilsight regarding the laws of terrestrial and celestial dynamics posed a further challenge to the authority of traditional learning. Besides disenchanted clerics, who resisted the new science on orthodox grounds, philosophers such as Glambattista Vico and the Third Earl of Shaftesbury combatted the hegemony of science for reasons chiefly pertaining to the unique claim to moral truth advanced by the humanities. The rallying point for both philosopliers--one which figured decisively in the Scottish school of Hutcheson, Hume, and Reid-was the notion of common sense dating back to the natural law doctrines of the stoics.20 Vico's opposition to the denigration of the arg topica and the ars poetica by anti-traditonalist Enlightenment thinkers merits singular treatment. The vitriolic attacks on language and tiadition provided a catalyst for Vico's own original defense of the humanities which ushered in a new phase of la querrelle des anciens et des modernes. Although vico was a teacher of rhetoric and was thoroughly steeped in the classical tradition, his own originality lay in elucidating the importance of historical understanding for achieving true selfknowledge. This substantial departure from Renaissance neo-classicisin had a profound impact on later Romantic humanists.

Vico began his career as a Cartesian but later rejected the superiority of the geometric and analytic 
methods on the grounds that they were of no use in practical life. The foundation of moral character. with its attendant emphasis on adapting conduct and speech to the changing circumstances of the moment (a view that harks back to Aristotle's phronēsis) relies upon those faculties of common sense, imagination, and memory which Bacon and Descartes had expelled from the realm of reason and located in the "passions." Vico did not dispute this placement so much as capitalize on it by arguing that the natural primacy of sensus communis conferred upon it in virtue of its embeddedness in the shared habics of traditional life enable it to quite literally found community and right conduct generally. Because a sense that appeals to the passions which compel men to act fosters at most a probable, nonapodeictio certum, it essentially issues in a multivalent truth reflecting contrary positions. 21

Vico takes this argument yet further by noting that even applied mathematics in physics and medicine possesses only probable truth. This observation is closely connected to his refutation of the Cartesian clain that apodicticity (clearness and distinctness) functions as a reliable criterion of knowledge, understood as the correspondence of idea and external nature. According to Vico, mathematics is known with certitude only because it is based upon conventions created by the imagination, not because it corforms to the inner reality of nature. ${ }^{22}$

The above animadversions contained in Vico's De Nostri Temporis studiorum Ratione (1709) do not yet elevate historical understanding to the premier rank accorded it by the scienza Nuova (1725), but they nontheless presage Vico's radical thesis that only what is created is truly knowable (verum et factum convertuntur). In vico's judgment truth and making are convertible because ultimate knowledge of the reasons and purposes for some thing or event, i.e., its genetic understanding per caussas, can only be had when the thing or event in question is of our own making. History, including the evolution of languages, myths, and socio-political institutions, is the creation of man and can be known from within as modificazione of individual and collective mind, i.c.. as expressions of need, desire, and purpose. Because external nature retains an opacity that is impervious to genetic understanding--only the divine creator can penetrate its inner secret--mankind can but externally observe its operation and attempt to recapitulate its uniformities by interpreting them in accordance with its own mathematical constructs. ${ }^{23}$

By extolling historical understanding (the capacity of the imagination to enter into its own creations) over intuitive reason, Vico set the trend for later developments in nilleteenth century Romanticism. Vico's critique of those attempts by natural law jurists such 
as Grotius, Selden, and Pufendorf to derive the principles of right from fixed, unchanging human nature, his contray view of human nature as a process, conditioned by culture and socio-political institutions, of coming to birth (nascimento), and his conception of hunian history as a progressive realization of selfconsciousness, strongly resonates in the tradition of Hegel and Marz. ${ }^{24}$ Nonetheless, his impact on later defenders of historical science, especially German historicists in the late nineteenth century, appears to be marginal.

The humanist tradition that informs Vico's philosophy of history and which continued to influence later verman Idealisin is first and foremost an ethical one. The guiding interests are twofold, namely the cultivation of moral character through the appropriation of common traditions and its nurturance in understanding the exemplary ideals of times past. This pedagogical model reached its zenith in Hegel's concept of Bildung which, in the context of the Phänomenologie des Geistes (1807), dencted the process of historical reflection whereby egoistic particularity is elevated to the plane of free, universal self-consciousness (Geist).

It was Nietzische who disabused Gerinan historiography of the pretensions of the Weltgeist, thereby contributing to the emasculation of historical humanism at the dawn of the twentieth century. More important, he once again raised the question concerning the historian's proper attitude toward the past. Vico did not explicitly address the problem of historical understanding ond he seems to have credited human fantasia with an iminelise capacity to imaginatively reconstruct the mente of bygone epochs. Indeed, it was not until the nineteenth century that philologists such as Ast, Wolf, and Schleiermacher began to write hermeneutic treatises dealing with this issue, which has since come to dominate debates over the role of scientific method with respect to the humanities. Apropos of the new direction taken by the controversy. it is particularly noteworthy that Vico's own rudimentary differentiation of two kinds of scientific knowledge, roughly corresponding to the modern distinction between understanding and causal explaration, anticipated the bifurcation of Geisteswissenscharten and Naturwissenschaften that figured so decisiveiy in the German intellectual milieu at the turn of the century.

\section{I I}

Vico redefined the conflict between two cultures in a way that proved to be prescient in liglit of neoKantian debates at the turn of the century; not only did he explicitly raise questions about historical understanding and j.ts relationship to practical knowl- 
edge, but he also formulated this issue in terms of a methodological antinomy.

The concerns that animate the controversy at the outset of the twentieth century are, indeed, principally methodological in nature and stem in large part from the emergence of the social sciences. Shortly after the publication of the widely influential Schiel translation of J. S. Mill's Logic (1863), German philosophers such as Helinholtz and Dilthey questioned the Englishman's thesis that the Geisteswissenschaften, no less than the Naturwissenschaften, had as their major aim the inductive formulation of behavioral and psychological laws for purposes of prediction. 25 Their doubts about methodological homogeneity in the sciences led them and their successors to inguire more deeply into the foundations of the human sciences. Are these sciences nomothetic or idiographic, descriptive or evaluative, explanatory or interpretative? If they rely upon historical interpretation, then how are they scientific in a way that ordinary understanding is not?

The Schmoller-Menger Methodenstreit in economics in the $1870^{\prime} \mathrm{s}$ and $1880^{\prime} \mathrm{s}$, the intense discussion among representatives of the Southwest German neo-Kantian school of philosophy regarding the difference between Geschichte and Naturwissenschaft at the turn of the century. and the Werturteilstreit $(1909-14)$ in sociology involving Weber, Schmoller, Tönnies, et. al. are some of the more notable precedents which have shaped the German intellectual climate of the contemporary age. These debates are of primary interest to us because they bring into relief profound differences in approach that serve to pinpoint the major thrust of Gadamer's arid Habermas' respective philosophies. As we shall later see, an accurate appraisal of Gadamer and Habermas cannot ignore their attempts to penetrate beyond the narrow methodological concerns of their predecessors to more primary questions regarding the basic objectives and interests underlying the social sciences as well as the philosophical status of understanding as a condition of social life generally. It is this direction of inquiry which leads them to retrieve the practical dimension of earlier humanist thought.

Each of the following debates can be read as sequential stages in the elaboration and radicalization of what initially began as a purely methodological dispute (the Methodenstreit) and became progressively more philosophical. In the Werturteilstreit the question concerning the relative weight and function of practical evaluation and understanding in the human sciences is explicitly addressed.

As its appelation suggests, the Methodenstreit was essentially a methodological dispute over what counts, or ought to count, as all adequate account of economic behavior. At the risk of oversimplifying somewhat, one 
could say that whereas Karl Menger believed that an adequate explanation of economic behavior consisted in showing that some speciric event follows, or is an instance of, observed regularities, 1. .e., general causal laws connecting types of behavior with recurring antecedent conditions, Gustav Schmoller maintained that because the patterns of economic life are contingent upon the historical self-understanding of social agents, an adequate explanation of economic behavior is only achieved when the reasons, or motives, social agents have for behaving the way they do are understood. It should be noted that neither Schmoller nor Menger discounted the importance of understanding and explanation as heuristic devices for gathering data and formulating hypotheses.26 However, it was Max Weber who first tried to accomodate a synthesis of understanding and nomological explanation in his farreaching notion of explanatory-understanding--a syncretism which has led to a great deal of confusion anong his epigones.

Weber also had to broach the problem of historical understanding bequeathed to him by Dilthey. Occasionally, Weber suggests that sinnverstehen involves attributing a psychological motive to an agent on the basis of empathetic identification, introspection, and correlation of the interpreter's own psychological states with observed behavioral regularities.27 on this reading, understanding would not be the terminus ad guem of sociological explanation, but would at most function as a heuristic device for formulating empirically testable laws of behavior--a view that was later defended by $T$. Abel in his essay, "The Operation Called Verstehen" (1948).2" Elsewhere, however, Weber subordinates causal explanation to the overall goal of rendering action intelligible. Moreover, he also notes that to the degree that behavior deviates from the ideal norin of purposive-rational (zweckrational) action and is motivated less by an objective calculation of ends and means than by value-laden considerations, the possibility of psychologically identifying with the agent and verifying the attribution of motives on the basis of observed behavior becomes increasingly remote. 29 In the introduction to Wirtschart und Gesellschaft Weber attempts to elide the problem of empathy altogether by asserting that social action can reveal its meaning or rationale directly in the same way that mathematical equations do." Recently, this theory of understanding has enjoyed widespread popularity among those philosophers of language, such as Alasdair MacIntyre and Peter Winch, who argue that. Verstehen involves elaborating the logic of language games by showing how an action is an instance of following a publically accepted rule."

The preceding discussion of interpretative methodology is not gratuitous, for it raises the conceptual 
and, hence, philosophical question regarding the very nature of understanding as such--a non-methodological issue which is integral to Habermas' and Gadamer's defense of a humanistic social science. Neither Schmoller nor Weber attempted to ground their defense of understanding conceived as a method of gaining access to sociological data in a deeper philosophical reflection on the constitutive nature of understanding with respect to sucial life as such. By construing understanding as a psychological act of empathy, they ignored its essentially Iinguistic, communicative structure. The methodological truncation of understanding is the reverse side of its subjectivization. Once understanding is redefined as communication and che latter is demonstrated to be constitutive of cultural reproduction, socialization, and social integration, then the decision in favor of a hermeneutic social science having practical intent becomes philosophically compelling.

The gradual orientation of the series of debates away from methodological to meta-theoretical concerns regarding the interpretative coustitution of society was undertaken by the southwest German School of Philosophy. Unlike their fellow neo-Kantians at Marburg, who mostly concentrated their efforts in examining the logical foundations of natural science--for them the prototype of all knowledge--the Baden school. whose leading figures were Heinrich Rickert and Wilhelm Windelband, focused their attention on the historical and cultural sciences. Beginning with Windelband's famous rectoral address of 1894 , the school attempted to redefine the distinction between the natural and cultural sciences without invoking any metaphysical dualisms between nature and spirit. 22 In so doing, they were primarily responding to Dilthey's pioneering strategy of philosophically founding the distinction between the so-called Geisteswissenschaften and Nacurwissenschaften on a dichotomy between the realms of mental life and external nature. Dilthey maintained that mental phenomena exhibit a narrative unity in which past, present, and future experiences interpenetrate one another. For Dilthey, this model of inner life dictated the proper aim of the social sciences and humanities, namely the restoration of past spiritual life to contemporary consciousness. Like vico and Schleiermacher before him, Dilthey believed that only spiricual objectifications were intelligible, or susceptible to empathetic identification (Einfühlen) and reproduction (Nacherleben)."3

Dilthey's tendency to lapse into a nature/spirit dualism and his apparent inability to account for the possibility of empirical psychology, conceived as a nomothetic discipline, led Windelband to discard the old distinction between Naturwissenschaft and Geisteswissenschaft in favor of a distinction between natural 
science and history (Geschichte). What distinguishes these two epistemological domains, he asserted, is not the subject matter of which they treat, but rather their fundamental cognitive goals. Natural science seeks to discover nomological uniformities for purposes of prediction and control. Historical science aims at understanding the meaning of individual events for purposes of practical enlightenment."

Rickert followed Windelband in framing methodological issues within the context of logical inquiry. Moreover, he developed Windelband' 8 distinction between nomothetic and idiographic science further. Windelband based this distinction on the logical difference between general and particular judgments; Rickert grounded it in a deeper ontological analysis of scientific concept formation. He particularly emphasized the value-relatedness (Wertbeziehung) of culture, maintaining that it alone was decisive for historical understanding. Whereas the natural sciences constitute their object field by means of generaliziang concepts, the cultural sciences do so by means of individuating concepts, or values. Rickeri's substitution of Kulturwissenschaften for Dilthey's Geisteswissenschaften indicates an attempt on his part to see the entire realm of culture as a transcendentally constituted field of normative objects that resist psychological reduction. However, because Rickert held fast to a psychological conception of understanding, he, like Dilthey, continued to think of understanding in terms of a factual, correspondence relution. This led him to eschew evaluation as a legitimate concern of the social sciences and to seek a non-relativistic, objective basis for historical inquiry in transhistorical cultural values. 's

Weber was enormously influenced by Rickert's hypothesis concerning the value-relatedness of cultural phenomena and its importance for concept formation in the social sciences. In the Werturteilstreit of 190914 the question regarding the role of value judgments in social science was debated among members of the Verein für Sozialpolitik. Despite the fact that Weber acknowledged the transcendental role played by values in constituting social life, even going so far as to concede that the guiding interests and conceptual apparatus of social inquiry are inextricably value-laden, he nonetheless continued to espouse the model of a werturteilfrei social science on the bais of a neo-kantian separation of knowledge and evaluation." As I noted abqve, this dulistic methodology directly emanates from a "divinatory" or "empathetic" conception of understanding that is charateristic of the school of Romantic hermeneutics from Schleiermacher to Dilthey. ${ }^{37}$ 
The series of debates outlined above form the common intellectual heritage of Gadamer and Habermas. As we have seen, the succession of controversies displays a continuous, progressive development culminating in a philosophical awareness that social life is "objectively" constituted by values which can only be disclosed in understanding. However, with the exception of some of Weber's and Dilthey's last reflections on the nature of Verstehen, one discerns a general tendency among neo-Kantian thinkers to psychologize understanding, thereby neglecting its essentially critical and evaluative nature. The net result of this line of thought is a kind of positivism which annexes all knowledge and science to the purely descriptive paradigm of the exact sciences.

The following section is concerned with examining several disputes in which Gadamer and Habermas explicitly confronted their neo-Kantian past. These debates are of signal importance to us because they serve to stress the basic conmonality underlying Gadamer's and Habermas' respective positions, namely, a rejection of a subjectivistic conception of understanding in favor of a communicative model and an affirmation of the deeply moral and evaluative character of the human sciences. They also provide a transitional stage to the final philosophical section of the historical analysis. First, as quasi-methodological disputes they demonstrate in the most profound way the limits of the exclusively methodological focus of the neo-Kantian tradition which prevent it from resolving some of its fundamental aporial. Second, insofar as these debates issue in a dialectical conception of understanding which encompasses cognition and moral reflection in a unitary Bildungsprozess, they already anticipate a Hegelian perspective.

The Betti-Gadamer Debate. The Betti-Gadamer controversy in the $1960^{\prime}$ s illustrates the degree to which Gadamer's hermeneutics deviates from the methodological and theoretical treatment of understanding so typical of neo-Kantian philosophy. Contrary to what one tinight be led to believe judging from their own remarks, Emilio Betti and Gadamer did not fundamentally disagree about any particular methodological or theoretical point. What they contested was rather the basic philosophical mise èl scene in which questions regarding the status of understanding in the human sciences were to be cast. Betti has made it clear that the Kantian task of settling the epistemological issue regarding the quaestio iuris of objective knowledge and truth applies foremost to the problem of understanding in the human sciences. " Subsequently, he sees this task as continuing the tradition of Romantic hermeneutics ex- 
tending from Schleiermacher to Dilthey, the principal aims of which were the articulation of criteria, including methods of procedure, and the classification of types. For Betti, as for Dilthey and Weber, the possibility of objective understanding rests upon the capacity of the interpreter to reconstruct the intentions of the author or agent. Thus, while allowing that evaluation and practical application may be appropriate in jurisprudence and theology. Betti remains preeminently a defender of a wertirei science of interpretation. Gadamer, in contrast, departs from the Heideggerian assumption that understanding and interpretation are ontologically constitutive of human existence (Dasein). Though he too maintains that the proper goal of hermeneutic theory is the justification of objective understanding and truth, he situates this project within the ambit of human historicity (Geschichtlichke1t) and the practical concerns generated within it. These concerng are inextricably bound to the formation of moral identity through participation in tradition. Hence, the notions of objective knowledge and truth which Gadamer seeks to vindicate have less to do with the attainment of correct, or valid interpretation, than they do with the transmission of culture. Given the ontological priorities of Gadamer's enterprise, which proceed from the indiepenwable role that traditional prejudices (Vorurteile) play in any disclosure of meaning, it is quite logical that he stress the eventfulness of understanding as a process which prescinds from methodological control. Similarly, his recovery of the rhetorical humanism of Isocrates and Vico must be understood in light of his conviction that the sensus communis which underlies all community and interpretation is the necessary outcome of an artful play of forces (or probable arguments) rather than of any demonstrative grounding.

Betti's hermeneutics is chiefly inspired by Dilthey's attempt to provide transcendental foundations for the Geisteswissenschaften. Betti maintains that the possibility of scientific understanding is contingent upon the objective ideality of values which are expressed in mental life. Values possess an absolute lawfulness which transcends personal caprice as well. as the vicissitudes of time and place. Such values can only be known insofar as they are objectified by particular individuals in linguistic symbols and dateable artifacts. Here Betti recurs to Willelm von Humboldt's theory of language and finds that his distinction between Sprache (language) and Rede (discourse), which prefigures Saussure's structural linguistic dichotoluy of langue and parole, captures the relationship between ideal noetic content and material expression. Understanding is always more than mere knowledge of the immediate signification of words used in speaking and writing; it also presupposes interpretative participa- 
tion in an ideal system of possible linguistic, aesthetic, emotive, and ethical values. It is only because signs are the material embodiment of intentions which are themselves instantiations of a transpersonal realin of values that meaning can be communicated. 3"

According to Betti, interpretation is the reconstruction of the author's original intentions. Contrary to Dilthey. Betti insists that this is not a psychological act involving empathetic transposition into the mind of the other so much as it is a logical process of discerning, as collingwood and others would have it, a probable rationale. Once the author's original intentions are known, Verstehen is achieved."

Among the more important metatheoretical conditions for the possibility of correct understanding mentioned by Betti are self-effacement and receptivity on the part of the interpreter. These capacities are themselves conditioned by a triadic dialectic of interpretation. At the two excremes of the dialectic are the mind of the author, which demands recognition as autonomous (an sich) and original, and the mind of the interpreter, which requires actuality (Actualitä), or the integration of meaning with respect to chosen theoretical interests and familiar cultural background. This antinomial relationship is mediated by the object of interpretation." Cleariy, the demand for actuality on the part of the interpreter limits the extent to which his subjectivity ran be efraced. Nonetheless, Betti warns against misconstruing this condition as an obstacle to attaining objectivity. With Weber, he argues that the Wertbeziehung of the hermeneutic situation need not nor should not interfere with the wertfrei conduct of interpretation. The interpreter cannor but be selective in the kinds of interests and cultural orientations which he brings to the subject matter. But this does not entitle him to impose his own point of view on it (what Betti calls Deutung as distinct from true interpretation, or Auslegung), nor does it condone appropriating its meaning for the sake of practical edification or self-confirmation--an abuse which Betti believes is especially prevalent among Heideggerian hermeneuts such as Bultmann and Gadamer, whose "existentialist" leanings putatively lead them tó subordinate considerations of ojectivity to subjective Schwärmerei and obfuscation. "2

Because of the actuality of interpretation, hermeneutic objectivity. Betti admits, does not entail that all correct interpretations of a given text necessarily coincide with one another. The historical diversity of Weltanschauungen insures that interpretation can never be complete or final." However, because the congealed meaning embedded in the objectification exists independently of the interpreter, no two interpretations reflecting the same interest and cultural horizon can vary substantially without one of 
them being false. Thus, hermeneutic objectivity implies an absolute criterion of truth, albeit, one that is relative to historically variable perspectives. Once the interpreter selects a specific range of meaningfulness. (e.g., the conscious as against the unconscious motives of an agent, the antecedents and consequences of whose actions are known by the interpreter with respect to his own limited historical horizon) the free-play of cultural assumptions theoretically remains marginal.

Betti lists four methodological canons which help guarantee accurate interpretaion. These stress the autonoiny of the object, the supposition of semantic completeness and coherence in the object, the actuality of understanding, and the harmonization of understanding with regard to part and whole. In addition to these canons, Betti follows his predecessors in the Romantic tradition by breaking the process of interpretation down into four theoretical moments. These consist of a philological moment (the reconstruction of the grammatical and logical coherence of spoken and written speech), a critical momenc (the explanation of incongruities and source analysis), a psychological moment (the reconstruction of the thought of the author as it reflects the spirit of his class, nation, etc.) and a technical-niorphological inoment (the interpretation of specific objectifications with reference to general categories, or laws of development, e.g., problemsgeschichte). Finally, Betti devotes the greater part of his work discussing three types of interpretation (cognitive, reproductive, and normative) which differ depending upon the weight given to the autonomy of the text over against interpretative actuality. Only in the case of normative interpretation involving, e.g., judicial and theological application, is it a legitjmate aim of interprecation to frame the meaning of the objectification within the context of practical concerns."4

Before proceeding to examine the specific charges which Betti levels against Gadamer, it might be useful to first look at the gravamen of Gadamer' $\mathrm{g}$ critique of Betti. Gadamer does not cavil over the methodological substance of Betti's work; he himself strongly insists upon recognizing the autonomy of meaning as the aim of objective understanding." The systematic classification of types of interpretation he finds generally acceptable, but here he is unwilling to abide by Betti's segregation of recognitive, reconstructive, and normative interpretation. Moreover, he questions whether Betti's own account of the dialectic of interpretation is compatible with such a division." If interpretation is a "mean" between textual autonomy and interpretative actuality, then any recognition of the original intentions of the author would a fortiori be reconstructive and normative, viz., it would necessarily en- 
large upon, or interpret, the meaning for purposes of communicating something of practical significance to the interpreter and his audience."

Gadamer believes that the preceding difficulty is symptomatic of a serious ambiguity which runs throughout Betti's hermeneutics. Despite his repudiation of Dilthey's assimilation of interpretation to Einfühlen and Nacherleben. Betti lapses into psychologisin when he conceives the process of reconstructing the author's intended meaning as an act of interiorizing his creative thought. Ihis neglects the important difference between understanding the significance of what the author intended to convey, e.g., some publically communicable message, and re-enacting his inner life. Only with respect to the former do considerations of objectivity pertain."

In Gadamer's opinion, the fatal defect of Romantic hermeneutics is its uncritical adoption of the Cartesian subject/object dualism along with its attendant notion of truth, understood as adequatio intellectus et re. Even if understanding were directed toward reexperiencing the psychic life of the other, the possibility of transcending one's own hermetic orbit of mental life and transposing oneself into alien spiritualities would remain enigmatic. Not only would such an identification actually preclude objective verification, but it would contradict the hermenisutic denand for actuality.

Once understanding is correctly conceived as the recovery of a pullically communicable nessage, then as Betti's own dialectic of interpretation suggests, the absolute bifurcation of interpreter and interpreted can no longer obtain. The message, which now functions as the standard of objectivity, is itself a Verschmelzung, or fusion, of "subjective" and "objective" horizons. True, or valid understanding is not the adequation of the mind of the interpreter is that of the author, but is rather an agreement (Verständigung) or commonality which is irreducible to the subjectivity of either."

If true understanding is agreement, them interpretation can only be a process of coming-to-agreement, or more precisely, dialogue. Ear from demanding the self-effacement of the interpreter, dialogue rather involves a mutual incerplay of arguments and divergent claims with the aim of reaching substantive agreement over soine issue which impinges upon the truth of the interlocutor's claim. Now because the claim of the other which confionts the interpreter is always the claim of tradition speaking through the text, it is fundamentally a claim that is addressed to his humanity and is, therefore, pre-eminently of practical concern to him, whether he acknowledges it or not. Consequently. Gadamer submits that understanding is practical dialectic, of Bildung, viz., it is nothing less 
than the reflective expansion of one's parochial horizons to encompass the point of view of the other.

Gadamer, however, does not rest content with this forinulation, for it leaves the cognitive status of understanding unclarified. The greater part of Gadamer's philosophical hermeneutic is intended to remedy this unclarity by justifying the humanistic belief in the epistemological credibility of the humanities and interpretative social sciences as conveyors of practical truth. Toward achieving this end, he invokes Heidegger's ontological conception of understanding. Presently. It suffices to note the outcome of this strategy. Simply stated, understanding for Heidegger ceases to be one anong many epistemic attitudes, or postures one can adope in experiencing the world. Instead, it assumes the stature of an Existentiale, or a priori structure of human existence. Qua Existentiale understanding is the interface between consciousness and world. As such j.t is an event (Geschehen) which is propelled by a play of forces extending beyond the control of the interpreter, the principal one's being his own prejudices, which prefjgure a horizon of possible meaning. The latier, in turn, implicitly refers back to the practical concern (Sorge) of the interpreter. In effect, the self-referentiality of understanding renders Betti's criterion of objectivity otiose. Because the personal situation of the interpreter is essentially implicated in the actuality of interpretation, there is no guarantee that two critically self-aware hermeneuts sharing the same general background, expertise, and point of view will concur in their interpretation of any given text." Vico's assessment of the rhetorical nature of practical knowledge, Gadamer contends that hermeneutic understanding. too, falls outside the purview of univocal truth and demonstrative certainty. Objective understanding, such as it is for Gadamer, can only be the outcome of a dialogical play of claims representing interpreter and text in which practical conviction rooted in passion and prejudice is ultimately decisive. 52

The possibility of practical truth, and not just correct understanding, absorbs most of Gadamer's attention. The fulcrum of his argument now shifts to a discussion of Heidegger's theory of historicity. The main thrust of his theory is that understanding is a process of cultural transmission in which interpreter and text are co-constitutive. The underlying unity of tradition, of subject and object, of past and present, etc.. generates an cver-arching cuntinuity whereby the claims of tradition are preserved and their validity extended. Once more, Gadamer appeals to the classical humanist tradition, in particular, Aristotle's concept of phronesis, in defending the idea of a universal truth which dynamically incorporates a particularized content. 51 
Betti's rejoinder to Gadamer's philosophical hermeneutic predictably attacks its refusal to come to terms with the epistemological problematic concerning the possibility of objective interpretation. Betti protests that the autonomy of textual meaning is violated once the interpreter's prejudices and his practical situation are seen as transcendentally constitutive of the text. Gadamer's attempts to salvage a "method" for securing the "scientific" rigor of interpretation perforce comes to grief." This objection is evell more incisively stated in E. D. Hilsch's critique of Gadamer. According to Hirsch, the "verbal meaning" intended by the author must be entirely separated from the "significance" it has for the interpreter-a view which eschews even the limited hermereutic dealectic advanced by Betti. The implication of this extreme view is that the meaning of the text must be "selfidentical" and "unchanging" in "different acts of construing." 1 s"

Gadamer believes that those prejudices which are productive for retrieving the author's intended meaning can be sorted out frotn those which impede and distort true understanding in a kind of dialogical encounter with past tradition. This encounter leads to a questioning of the interpreter's own prejudices as well as to a siftirg out of anachronistic eleinents in the text. The process reaches completion when the meaning of the text exhibits inner coherence and agrees with the author. The Heldeggerian extension of the hermeneutic part/whole circle to embrace subject and object requires that the meaning of the text appear reasonable and truthful to the interpreter. In Betti's opinior, this amounts to conflating the canons of interpretative coherence and actuality with accuracy; the prejudice structure of the interpreter, rather thall the perspective of the author is held to be decisive for true understanding. Subsequently, Gadamer's progressive reduction of interpretation to dialogue and selfunderstanding forces him to collapse the distinction between philological, historical, and juridical/theological methods of interpretation."

The Fositivismusstreit. The Positivismusstreit in the early 1960's pitting Karl Popper, Hans Albert, Harald Pilot and other so-called neo-positivists against critical theorists including Jürgen Habermas, K-O. Apel, and Theodor Adorno, bears a stronger resemblance to the fin de siècle debates discussed earlier than does the Bett $\bar{i} /$ Gadamer controversy, for it is concerned with the role and function of scientific method in the social sciences-an issue which, if at all, only emerges tangentially in the former debate. In the betti/Gadamer controversy the question concerning, for example, the role of nomological explanation in the humanities is simply not raised. Second, both sides in the 
Positivismusstreit appeal to the Kantian heritage in defending their respective positions, so that the debate always proceeds at the level of epistemology, never ontology. Prima facie, the Positivismusstreit appears to be a recrudescence of the Methodenstreit.

That this is not the case, however, becoines apparent when we examine the context in which methodological issues occur in the debate. The epithet Positivismusstreit is a misnomer, for both sides reject the old logical positivist doctrines concerning verificationism and the "given." Nonetheless, Karl Popper and his supporters share some assumptions with the older members of the Vienna School, namely, that all knowledge is (or ought to be) regimented by a unified method and that this method is defined by the hypothetical-deductive procedures of the exact sciences. This has led $\mathrm{K}-0$. Apel to observe that the neo-positivists have restricted transcendental reflection to the methodological concerns of the logic of science or have abjured it altogether (Gadamer makes a similar observation with respect to Betti's hermeneutics). Whereas critical theorists maintain that epistemological inquiries must incorporate a radical philosophical reflection on the basic social interests which validate our different modes of cognition, the neo-positivist hypostatize the methodological aims and irterests of science as absolute.

Une can glimpse something of Rickert's and windelband's transcendental approach to epistemological issues resurfacing in the critical theorist's position. however much the latter reject the former's separation of facts and values. Conversely, Popper and Albert. essentially adopt a Heberian stance with respect to the role of values and value judgments in scientific research. To be sure, the neo-positivists do not deny the practical consequences of the social sciences. Indeed, they rather see these sciences as implementing social criticism and political rationality par excellence. Still, the separation of knowledge and evaluation forces them to construe practical rationality in the same narrow instrumental terms that Bacon and Hobbes did. The critical theorists, on the contrary. seek to rehabilitate classical political theory and its claim to offer ethical enlightenment. In pursuit of this end, however, it is not the rhetorical humanism of Isocrates and Vico to which they return, but rather the field of transcendental ethics that, with the exception of Scheler and Hartmann, had all but been abandoned by contemporary German philosophy.

I shall limit my exposition of the positivismusstreit to the contributions of its principal participants. Karl Popper and Jürgen Habermas. In his celebrated essay. The Poverty of Historicism (1957) Popper promotes the idea of a techmological social science geared towards engineering incremental changes in vir- 
tue of what he perceives to be the ineluctable selectivity of empirical knowledge. Such a social science would abstain from making the kinds of holistic, teleological predictions which he accuses historicists of prescribing in favor of proffering conditional prognoses based upon observationally corroborated behavioral laws. The chief advantage of the research strategies of the exact sciences as Popper sees it is their production of a cunulative, systematic growth of knowledge which is capable of yielding technologically useful predictions."

Popper repeatedly draws attention to the importance of the experimental method as the hallmark of rationality. Although Popper defines truth as the correspondence of laws and independently existing regularities, he nonetheless rejects the positivist doctrine of the "given," arguing that all observational statements. which for Popper predicate over material objects rather than sense-data, are "theory-laden" and, therefore, conventional. Popper also rejects verificationism on the grounds that, owing to the selectivity of experimentation, one cannot absolutely confirm the truth of any hypothesis but can at most show that it approximates a high degree of verisimulitude. Thus, experimentation is a critical process that tests those particular instances whjch potentially falsify a given hypothesis. The empirical content of a law, or its predictive usefulness, is directly proportional to its falsifiability, or the number of potentially falsifiable instances which can be deduced from it."

According to Popper, the scientific method is the rational articulation of a natural process of trial-byerror learning. Rationality is conferred upon this method in virtue of its objectivity, which Popper conceives to be a function of mutual criticism among members of a scientific community. The single most important precondition of objectivity is avoiding "the confusion of value spheres and (separating out) extrascientific evaluation from questions of truth." Value judgments, though figuring in the choice of problems and the adoption of standards, are not rationally demonstrable; the commitment to scientific rationality is itself expelled to the beyond of pre-rational faith. Yet normative decisions are not entirely resistant to objective evaluation. Normative discourse must promote the free expression of competing opinions in which the force of the better argument prevails." Moreover, values can be evaluated both in terms of their overall consistency with one another and in terms of their consequences. Given preference scales, one can empirically calculate which values are optimal means for realizing pre-given ends.

The exclusion of value judgments is a fait accompli at the level of truth testing. Here, the replicability of experience as the impartial arbiter compels the in- 
dividual scientist to standardize observational data by reducing it to measurable quanta. 12

Popper does not deny the importance of verstehende Soziologie for explaining the actions of individuals, though he sees its function as largely propadeutic to the overall aim of formulating general behovioral hypotheses. In defending the scientific integrity of understanding, he distinguishes subjective, or psychological understanding from objective understanding, which he takes to be fourdational for both psychology and social science. Like psychological interpretation. objective understanding explains intentional behavior by specifying a causal relationship between antecedent motives and consequent acts; it is not oriented toward the psyche of the agent, so much as it is aimed at rationaliy reconstructing the situational logic of his action. Understanding consists in "realizing that the action was appropriate to the situation"--a view which apparently depends upon the assumption that psychological elements such as motives, desires, purposes, etc.. are logically connected to certain kinds of observable situations." 3 Popper further maintains that the social situation is structured by linguistic conventions, traditions, and other social institutions of which the sociologist must have some "participatory" understanding. For this reason, he sharply criticizes the ideal of detached, impartial observation so typical of behaviorism, asserting that it harbours a false notion of scientific objectivity."

Habermas' initial contribution to the controversy contains a mixed reaction to Popper's social theory. In the main; he accepts the notion that the social sciences must proceed in a generalizing manner by establishtuy law-1ike dependencies. His objections, he tells us, are not aimed at research practices in the exact sciences nor at those in the behavioral social sciences. Indeed, he acknowledges that the latter can "be called upon as an auxillary science for rational administration." What he disputes is the so-called "unity of method" thesis that subordinates interpretative sociology to a mere ancillary status within the broader orbit of technological prediction and control. The danger of such a reduction resides in the de facto exclusion of value judgments from the province of scientific rationality. Habermas does not dispute the necessity of this exclusion within the methodological compass of the exact sciences." However, when this exclusion is rigorously maintained at the level of social application, the ultimate ends of scientific engineering lose their rational mooring. There is the danger that a community of scientists isolated from everyday social life will choose their problems and solutions on the basis of arbitrary, subjective derisions that have little to do with the real interests of society at large. Horse still, cynicism with respert 
to the plurality of values may lead them to simply adopt pari passu the dominant point of view of the status quo, a concession which could conceivably lead to the perpetuation of the privileged interests of powerful classes. Einally, the intentio obliqua of a purely behavioral social science, as Adorno astutely noted, would justify the supercession of popular denocracy in favor of a technological administration composed of managerial elites." These dangers do not abate when Verstehen is enlisted to secure the data base, for the underlying social institutions which determine the situational logic of action are taken for granted. Once the situational logic is understood, it yields predictions intended solely for use in inanipulating passive social nature.

The major difficulty with the unity of method thesis, Habermas declares, is that it acknowledges only one kind of problem and one kind of rationality. namely, the technological task of discovering the optimal means for realizing values whose validity remains, aside from consistency testing and utilitarian calculation, beyond the scope of rational critique. Here, Habermas reminds us that there are aiso social problems of a distinctly ethical nature that cannot be resolved through technological engineering. These problems revolve around identity crises which occur whenever widespread dissatisfaction with the social roles mandated by society arises. The ultimate source of anomie and alienation is the inability of society to live up to its ideal of the "good life." Traditions and social institutions "ideologically" legitimate relations of power and distibution which do not fulfill the promises and rewards implictt in their legitimation. This kind of contradiction is not revealed by a mere superficial understanding of the situational logic of particular kinds of action. It also requires placing such action within the context of society taken as a whole, conceived as a teleologjcal process. This deeper kind of understanding-what Habermas calls "ideology critique"--critically evaluates existing traditions and insticutions which shape human character and action in light of their implicit ideals. Its modus operandi is ethical enlightenment through reflection rather than instrumental control achieved by experimentation."

Ideology critique, then, is governed by an ideal of rational action which is distinctly ethical in nature. It refers to action which is juth emancipated from the inner constraincs of ideology and cognizant of universal interests which possess a culturally enduring "truth." Now the repudiation of wertfrei sociology has methodological implications which violate Popper's interdiction against holistic, teleological explanation. Habermas notes that there is a basic asyminetry between natural laws and social regularities. Social regularities often assume the compulsory form of invariant 
causal uniformities because of their habitual "ideologically frozen" character. This tendency is exacerbated in "bourgeois" society because of the "reification"--to use Georg Lukács" expression--of social relations, i.e., the fragmentation of social relations and the regulation of interaction in accordance with the impersonal and seemingly immutable laws of the market. However, unlike the static character of natural laws, ideologically frozen uniformities are norms "posited under threat of sanctions" whose validity is contingent upon the voluntary recognition of social agents." When identity crises occur, this recognition is withheld and the fundamental organization of conduct is altered. In order to comprehend these changes, social laws must be construed as dynamic processes which ultimately feed into the overall ideological maintenance of society.

Habermas' defense of a critical-hermeneutic social science ultimately rests upon a transcendental analysis of cognitive interests. Popper is taken to task for not pursuing his methodological inquiries far enough. Although he recognizes the theory-laden and, therefore, value-iaden, nature of observation statements, he insists upon defending a correspondence theory of truth which postulates an independent criterion of corractness. Instead of returning to pre-critical epistemology. Popper, Habermus submits, should have more carefully explored the necessary conditions underlying the possibility of scientific truth in general. Here Habermas explicitly appeals to the Gadamerian notion of a "pre-understanding" which "anticipates" a horizon of possible meaning. According to Habermas, the meaning of the truth of empirical statements in the exact sciences is only made tully intelligible once it is situated within a broader pragmatic context. Scientific knowledge is valid in the most general sense because the norms and standards which govern scientific methodology and deterinine the very constitution of observation statements are themselves valid. This validity. however, does not rest upon a profession of faith as Fopper would have it, but is transcendentally grounded in a basic cognitive interest (erkenntnisleitende Interessel in technical control. Such an interest has the force of a transcendental orientation insofar as the production and reproduction of social life necessarily, depends upon the domination of external nature."

The transcendental certification of the exact sciences limits their range of application to problems of a strictly technological nature. In his final rejoinder to Popper and Albert, Habermas argues that critical-hermeneutic social science also circumscribes a field of action that is transcendentally constitutive of social life, namely, that of communication. Communication is the domain of activity in which ethical 
problems and, therewith, problems of identity arise. Because Habermas maintains that these problems are ultimately resolved by critical reflection, he designates the operative cognitive interest of the criticalhermeneutic social sciences "emancipatory." Habermas again reproaches Popper for neglecting to notice that the community of scientists and the discursive framework within which they criticize one another--what Popper himself advances as the political ideal of an "open society"--presuppose ethical assumptions, including the ideal of an unconstrained consensus achieved under domination-free conditions. From this point of departure, Habermas proceeds to argue that the sphere of communicative action is capable of founding a comprehensive rationality in which truth as such is redefined as ideal consensus."

Thus, by pursuing the same direction of thought implicit in Gadamer's rejoinder to Betti. Habermas' critique of Popper concludes by retrieving the primordial foundation of understanding in everyday communication. Seen from this vantage point, understanding is not so much a successful reconstruction of the intentions of authors and agents as it is an agreement, or consensus, about a shared meaning. In social life as in textual interpretation, this consensus is normative, viz.. it is fundamentaliy a question of mutually recognizing the legitimacy, or truth, of those practical claims with which society and tradition confront us. What is at stake in both cases is the reflective cultivation, or Bildung, of inuividual and societal consciousness. So construed, interpretation becomes the vehicle by means of which consciousness emancipates itself from parochial or ideological integuments and acquires a universal cosmopoliton perspective.

In restrospect, the recovery of everyday communication as the guiding idea underlying hermeneutic inquiry marks a decisive turn away from the methodological obsession of twentieth century philosophy of science. It also coincides with a reassessment of classical humanist thought. Nevertheless, it is evident that Habermas does not approach the problem of justifying the practical validity of the human sciences from the same direction as Gadamer. For Gadamer, the problem is ontological: it is a question not of what we ought to do, but of what happens to us over and above our doing. ${ }_{2}$ Philosophical hermeneutics can inform us about the nature of practical truth and how such truth is generated in cultural transmission, but it cannot proffer prescriptive enlightenment. Conversely, the emancipatory interest of ideology critique cannot rest satisfied with describing, much less legitimating, the authority of tradition. The criticaliprescriptive thrust of ideology critique demands recourse to transcendental reference points. Ultimately, it substi- 
tutes the model of psychotherapeutic discourse with its methodological presuppositions for Socratic dialogue.

The above reading of the controversy easily lends itself to a political interpretation that has gained wide currency among many commentaturs. On the one side stands the refractory conservativism of philosophical hermeneutics, whose major aim is the advancement of social solidarity founded upon continuing tradition. On the other side stands the intractable radicalism of Critical Theory, which ostensibly defends the Enlightenment credo of critical reason and individual autonomy. Whether this is an arcurate assessment of the Gadamer-Habermas controversy is a inoot question, yet there is undoubtedly some truth in the claim that the two philosophers approach the estimation of tradition from widely divergent Weltanschauungen. "I

\section{V}

We began our historical inquiry with the intent to illuminate the common ground uniting Gadamer and Habermas. It was established at the outset that they share an overriding concern to defend the moral and evaluative status of the human sciences, a fact which puts them squarely on this side of the ancients versus moderns quarrel. Next, we saw that they justify this position by repudiating neo-Kantianism and, more specifically, by appealing to deeper, philosophical considerations pertaining to the communicative structure of understanding, itself collceived by them as the fundamental vehicle of individual and social Bildung. I shall now endeavor to show that for joth Gadamer and Habermas this appeal is essentially nace with hegel in mind. In particular, it seems to me that their respective appropriations of Hegel converge at five points. First, both philosophers accept Hegel's critique of the subjectivistic and ahistorical nature of Kantian transcendentalism; for Hegel, Geist (Spirit) is prior to subjective mind. Second, they retrieve Hegel's concept of experience, which denotes a reflective process of self-cultivation culminating in progressively higher stages of freedom and sociality. Third, both Gadamer and Habermas recur to key texts (the Logik and the Jena system respectively) in holding that Hegel's concept of experience is essentially linguistic and dialogical. Fourth, they retain the Hegelian ideal of an umlimited community of perfect reciprocity while, fifth, rejecting his conception of absolute knowledge and his attempt to assimilate historical practice to philosophy.

Despite these symmetries, it is nonetheless apparent that Gadamer's Hegel is noc Habermas'. Three differences especially stand out in this regard. While Gadamer emphasizes those elements of Hegel's notion of reflection that link the achievement of universality. with growth inco new cultural horizons and the preser- 
vation and extension of tradition, Habermas underscores those aspects that stress the opposite, emancipatory achievement of reflection whereby tradition is deprived of its dogmatic power over the individual. This difference of accent carries over into their respective conceptions of plilosophy. Philosophical hermeneutics is essentially retrospective in orientation, viz.. it reflects upon the historical substance that conditions our subjectivity as exemplary for moral practice. Critical Theory, in contrast, is prospective: its reflection on the past is shaded by the anticipation of an emancipated form of social life. Finally. Gadamer and Habermas appear to stand on opposite ends of the spectrum concerining Hegel's famous dictum that the real is what is rational and that the rational is what is real, the former interpreting it as an ontological claim about a reason already realized, the latter interpreting it as a cousterfactual claim about a reality that is not yet rational.

I propose to begin my treatment of the HegelGadamer and Hegel-Habermas connections by briefly recalling the nineteenth century debate between "old" and "young" Hegelians which, I belleve, directly addresses the last and perhaps the most crucial difference between the two philosophers. Folloying these prefatory remarks there will be a more detailed analysis of the relation between them and Hegel.

Habermas, Hegel, and the Critical Tradition. Cadamer sees in Hegel's thought the seminal inspiration for all twentieth century critiques of the subjectivist elevation of abstract individual conscience above society and tradition. Habermas, on the contrary, interprets Hegel's masterpiece as the ne plus ultra of critical rationalism. That both thinkers should appropriate Hegel for what appear to be diametrically opposed purposes is neither surprising nor unprecidented. The nineteenth century dispute over the relative priority of ontological over axiological interpretations of Hegel's system pitting the "old" (right) Hegelians against the "young" (left) Hegelians remarkably prefigures much of the Gadamer-Habermas controversy. As Karl Löwith astutely notes, the schisin of the Hegelian school was made pussible by the ambiguity of Hegel's notion of Aufhebung, which connotes both preservation and regatior, and his dictum that the rational is what is real and the real is what is rational."

The old Hegelians, such as Karl Rosenkranz and Rudolf Haym, emphasized the moment of preservation in Aufhebung, which for them meant the restoration of Christian dogma in the Hegelian theodicy of spirit. Religiously and politicaliy speaking, Hegel's system was taken as a demonstration of the reconciliation of the individual with state and God. They maintained that because reality was rational-for Rosenkranz this 
entailed that social and political institutions, such as international commerce, technology, and mass publicity., were succeeding in reducing the "particularity" of diverse nationalities and classes to the universality of a uniform civilization--ethical philosophy, understood as the moralizing of would-be reformers, was presumptuous. "5 Haym was less optimistic about the capacity of the Hegelian ediface to withstand the challenge of modernity. Nevertheless, he subscribed to the old Hegelian shibboleth that philosophy is essentially retrospective, viz.. that in surveying the historical genesis of humanity, philosophy can only reveal truth ex post facto--as something which determines what we are but not what we ought to be." This view of philosophy resonates in the denouement of Gadamer's magnum opus as well: "In understanding we are drawn into an event of truth and arrive, as it were, too late if we want to know what we ought to believe."is

The "young" Hegelians, consisting of radical theologians, including David Strauss and Ludwig Feuerbach, and political reformers such as the Bauer brothers, Arnold Rüge, and Karl Marx, stressed the negative, or critical side of the Hegelian dialectic as well as the irrationality of phenomenal existence. The goal of philosophy as they conceived it was not the contemplative appropriation of the past but the future realization of its truth, namely the ideal reconciliation of individual and society which is metaphysically articulated in the Hegelian corpus. 70

Habermas' philosophy, and Critical Theory generally. take up the theory/practice problematic as it was developed by Marx and the left Hegellans. For the early Marx the concept of labor developed by Hegel in the Phänomenologie was the key to bridging the caesura between totalizing reason (Vernuntt), whose telos is the overcoming of alienation and the reassertion of an overarching unity of Spirit and nature, individual and society, etc., and actual social life. According to Marx, Ilegel's.theory of labor grounds the historical cultivation of reason in the metabolic satisfaction of needs that arises whenever the laborer objectifies himself in nature. Through self-objectification the laborer acquires, as it were, a permanent, independent image of his spontaneous productivity and his affective needs states upon which he can then reflect and gain a sense of objective self-confirmation. Labor becomes for Marx the primary vehicle of critical selfreflection; every labor-induced change in nature brings with it a new act of reflection and a corresponding discovery of new needs, or change in self-identity. which in turn necessitates a further act of labor. Labor not only reconciles man and nature but, insofar as it is social labor, it makes the satisfaction of other's needs a necessary condition for the satisfaction of one's own. In essence, Mars transfers the pro- 
cess of rational Bildung from the ethereal plane of abstract philosophical contemplation as it exists in Hegel's mature political philosophy to that of concrete practice.

Habermas strongly objects to the assimilation of ethical Bildung to the category of labor, which involves first and foremost the instrumental satisfaction of material needs. Because of this narrow epistemological foundation, Marx, Habermas argues, occasionaliy equates social rationalization with the efficient technological organization of the means of production. Moreover, some of his later characterizations of historical materialism lend one the impression that changes in the forces of production, above all, technological innovations, "cause" changes in the social relations of production, which in turn, "cause" changes in the political and cultural superstructure. To counter this onesided instrumentalism, Habermas returns to Hegel, this tine, however, focusing on the latter's early theological writings and on his Jena philosophy of mind.'?

In the Jena manuscripts Hegel interprets spirit (Geist) as the intersection of three irreducible media: family, language and labor, each of which is a constitutive component of human life. Language, the medium of symbolic representation, is the chief mechanism of social integration, since it is by means of communication that individuals come to share a common moral identity based upon reciprocal expectations. Labor. the medium of need gratification (but not the medium of need cultivation) only enables one to achieve a primitive sense of self-certainty with respect to nature.

Now the idea that linguistic communication is the fundamental medium of reaching a mutual uriderstanding about common norinative expectations reappears in the argument of Erkenntnis und Interesse (1968), where Habermas introduces it in conjunction with his criticism of Marx's epistemology. As a critique of Kant's notion of a transcendental ' I', a subjectivity that ostensibly possesses a perfect identity and freedom prior to social interaction, Hegel's philosophy of mind can also be applied to Marx's equation of labor and selfformation; the latter, Habermas observes, reflects Marx's Eichtean transposition of Kant's notion of transcendental synthesis onto the instrumental activity of an embodied monad. Hegel's philosophy of mind suggests, however, that communicative interaction and not instrumental labor is the primary vehicle of ethical cultivation. Consequently, the would-be critic of ideology must come to grasp the mechanism whereby collective illusions are generated as itself a function of psychological repression caused by the violation of communicative reciprocity."

Once again, it is the early Hegel to whom Habermas recurs in rectifying Mars's onesided materialisil. In 
one of his early theological fragments Hegel wrote that the abrogation of a moral totality by the criminal leads to the suppression of the moral iffe binding him and his victim. This violation of reciprocity issues in a "causality of fate" which is experienced by the criminal as an overwhelming compulsion to atone for his guilt. In Habermas' opinion, the allenation of the criminal from his social identity exemplifies the peculiar causality of fate that occurs whenever the reciprocity between social classes is violated." The ideological suppression of those emancipatory interests that would otherwise find linguistic expression invariably produces identity crises, anomic social relations ard, ultimately, political strife."2

"lhe "self-formation of the species," then, is not merely humanity's struggle to emancipate itself from the constraints of material reproduction as Marx maintained, but it is also a struggle to achieve mutual recognition under conditions of unconstratned communtcation. Habermas believes that at o certain stage in the social evolution of the human species, survival (culturaliy defined) can only be maintained when knowledge is elevated to the rank of science. Science, in turn, is a discursive, collective endeavor that requires freedom of thought. This relationship between science and reflection is given an incisive interpretation by Habermas. Citing the famous introduction to the first edjtion of Fichte's Wissenschaftslehre, Habermas argues that the interest in knowledye for its own salse converges with the practical interest in emancipation, the middle term of the relationship being reflection (Eichte's intellectual intuition). For Eichte, the decision to achieve transcendental knowledge rests upon a prior, practical decision to free oneself from all dogmatic constraints and, in effect, become totally rational, i.e., perfectly selfdetermining and self-transparent at one and the same time. Of course, the assumption that this act of reflection results in absolute knowledge, namely, the total fusion of self-knowledge (practical interest) and knowledge of reality (theoretical interest) is an aspect of Fichte's idealism which Habermas rejects. Habermas here sides with Marx's materialist critique of German idealism, a decision which leads him to assert that the emancipation from the internal constraints of dogmatic traditions and ideology can only take place within an intersubjective medium of the sort characteristic of psychoanalytic deptli-interpretation, which combines dialogue with a theoretically articulated, functionalistic explanation of symptoms.'

. In the remainder of this section I would like to iliustrate the significance of Habermas' rescoration of Hegel in light of some of the difficulties that plagued first generation critical theorists in their attempts to carry forth the Marxian tradition. Having descencied 
from the Marxist tradition, critical theorists were, a fortiori, self-proclaimed proponents of rationalism. Nevertheless, their understanding of Marx's ambivalent portrayal of bourgeois rationality, which was reinforced by their reading of Weber's unflattering analysis of social rationalization, led them to adopt a sceptical posture with respect to the prospects of founding Critical Theory. By accepting the neo-Kantian premisses of Weber's social theory and rejecting Hegel's dialectical philosophy, the leaders of the early Erankfurt School foreclosed any possibility of retrieving a notion of practical reason grounded in communicative understanding.

From the moment of its inception in the early $1920^{\prime} \mathrm{s}$, the founders of the Institute fur sozialforschung conceived their task as the critical revision and application of Marxist theory to accomodate contemporary developments in captialist society. The major problems they addressed themselves to concerned the paradox of rationalization inherited from Weber's probing analysis of modernity and the inability of orthodox Marxism to become the theoretical weapon of the proletariat as it was intended to be. Now the theory/practice problem as Marx understood it bears upon the monumental project of devising an empirically valid (1.e., scientific) social theory having practical inport. For Marx, social theory is to enlighten those to whom it is addressed about their true interests and function in society so that they can begin to plan their historical destinies in a rational manner. Consonant with his Enlightenment uutlook, Marx believed that the Naturwüchsigkeit, or nature-like development characteristic of the adventitious. spontaneous evolution of pre-bourgeois societies--a mode of development embedded in the dark sediment of preconscious traditions, including the parochial impediments to rational conduct typified by familial, regional, racial, and religious patterns of life--would be gradually eroded in the process of secularization initiated by the industrial revolution." The dissolution of tradition notwithstanding, Marx was aware that the acquisitive. self-serving behavior of competing entrepreneurs in an unregulated market--what utilitarian thinkers had earlier acclaimed to be rational conduct par excellence--would necessarily produce fortuitous events at the macro-economic level, as evidenced by recurrent business cycles. Consequently, he believed that the only solution to the problem of rationality deficits in capitalist society was the revolutionary overthrow of class domination and the establishment of a socialist soclety spearheaded by an enlightened proletariat.

Clearly, what Marx envisaged as rational conduct was not the enlightened egoism of Adam Smith, but rather presupposed the attainment of a superior vision of the pervasive sociality underlying the production 
and reproduction of human life. The common thread uniting Marx's later notion of class consciousness and his earlier characterization of human nature as Gattungswesen (species-being) is the ideal of an emancipated society in which mutual recognition is universally extended to all persons regardless of parochial ties.' The major obstacles to achieving class consciousness, in Marx's judgment, were ideology and commodity fetishism, both of which depict humanly cruated relations as if they were timeless and universal. Commodity fetishism is caused by the depersonalization of social relations brought about by mometarization (the reduction of labor to an exchange-value) thereby creating the illusion that social relations among persons are natural processes among isolated things. Ideology, in contrast, involves the manipulation of the cultural superstructure, including the reshaping of traditions, for purposes of legitimating the interests of the ruling classes. Though Marx believed that labor organizations would engender authentic feelings of social solidarity, he was well aware that isolated enclaves of proletarian militancy were particularly vulnerable to the divisive appeal of regional and cultural prejudices. Subsegueritly, he maintained that praxis unaided by a scientific criticque of political economy is blind." Das Kapital is ideology critique in the dual sense that it exposes the lie of equal exchange in the production of surplus value and shows that the mechanism of capital accumulation is ulitimately contingent or the "voluntary" participation of dispossessed producers.'

Later critical theorists, however, observed a tension between the theoretical foundations of Marx's sociology, which he appropriated to a large degree from the natural sciences, and his application of 1 , which displayed a remarkable sensitivity to the dialectical interdependencies subsisting between social consciousness, politics, and economics. The clearest and, as Marx and Engels themselves later came to regret, the most one-sided formulation of the relationship between the cultural/political superstructure and the economic base is found in the famous preface to A Contribution to a Critique of Political Economy, where Marx states that it is not the consciousness of men that determines their existence, but their social existence which determines their collsciousness."

One cannot underestimate the powerful influence that orthodox Marxism exerted on the members of the Frankfurt School. Nonetheless, their acceptance of Marxian tenets was not without reservation. The orthodox theory, they argued, overlooked the tenacious hold that authoritarian patterns of thought continue to have on the individual in bourgeois society. Their discovery of Freud in the 1930's corroborated their suspicion that the extent to which such patterns are entrenched 
in the most basic of all social units, the family, all but precluded an optimistic, economically based forecast of the revolutionary potential of the proletariat." The intransigency of ideology, conceived as a mass-cultural phenomenon embracing the very linguistic base of social consciousness as such, and the transference of legitimation functions from the economic sector to the political sphere in post-liberal capitalism, led them to subordinate the critique of political economy to Kulturkritik."

The School's understanding of the crisis afflicting contemporary bourgeots culture was principally shaped by the widely influential study of social rationalization undertaken by Max Weber. Like Marx before him, Weber was keenly aware of the fragmentation and dehumanization of modern society--maladies which he identified with loss of meaning and loss of freedom respectively. Though he admired the innovative potential of modern science and 1 ts methodological institutionalization of progressive, cumulative learning processes, he also appreciated the considerable cost that a technocracization of society exacts from the human spirit. The ascetic, methodical lifestyle of businessmen, professionals, and bureaucrats demands repression of self, one-sided vocationalism, and rigid conformity to rules and procedures. The global adminsistration of life by the state and the subsunption of work under conditions of efficient production is vividly captured in Weber's pathetic image of modern society as a steel cage." The technocracization of everyday life is also a principal source of anomie. For Weber, the regulative idea of an enlightened community of Kulturmenschen in which transcendence of parochial prejudice is combined with acceptance of pluralism is the reverse side of the relativistic depreciation of traditional values engendered by positivism and historicism. Cultural enlightenment is accompanied by a "new polytheism" revolving around a consciousness of the fragmentation of value orientations and lifestyles, none of which any longer possesses validity. The nihilistic implications of a positivistic repudiation of value-rationality are directly mirrored in the polarization of modern humanity into Fachmenschen ohne Geist and Genussmenschen ohre Herz (specialists without spirit, sensualists without heart), forms of life that exemplify the schizophrenic instability of a consciousness devoid of firm value connitments. Given this pessimistic appraisal of modernity, Weber could find no way to resolve the paradox of rationality other than by appealing to a revival of culture inspired by pre-rational charismatic authority. 92

It was Lukács' Geschichte und Klassenbewusstsein 11922) that provided the link, so crucial for later critical theorists, between Marx's analysis of commo- 
dity fetishism and heber's analysis of rationalization. Lukacs' critique of reification was premissed on the assumption that the fragmentation and depersonalization of commodity fetishisin and the objectification of analytic reason (Hegel's notion of Verstand) are two aspects of the same bourgeois "form of objectivity" (or mode of being and knowing). Opposing the neo-Kantian presuppositions of Marxist revisionism and volunteerism, Lukács sought to resolve the theory/practive problem in a manner that, in retrospect, appears to be strikingly reminiscent of the praxis philosophy espoused by. the young Mary in the as of yet unpublished Manuscripts. Returning to Hegel's speculative dialectic of subject and object, Lukács argued that the central position occupied by the proletariat at the dynamic point of production would enable it. to penetrate through reified social relations thereby, in effect, becoming the identical subject-object of history."

This return to Hegelian idealism, with its attendant belief in a speculative identity of thought and being, was later rejected by critical theorists. Irstead of pursuing the path of dialectical philosophy, however, they all but abandoned it in favor of a position that by and large remained faithful to the old neo-Kantian dualism of "is" and "ought." Nevertheless, their dissatisfaction with this tradition of thought and their concern over the problem of practical and philosophical reason, led them to examine the relationship between scientific method, philosophical reflection, and truth. During the 1930's the school cont1nued to stress the importance of incorporating an empirical study of political economy in their interpretations of cultural life. However, the contribution of scientific method in ideology critique was explicitly confined to the preliminary stage of collating data and formulating hypotheses; the interpretation and evaluation of data was assigned to critical reflection. By and large, the School remained hostile to positivism, an opposition that was most clearly articulated in Max Horkheimer's manifesto, "Traditionelle und kritische Theorie" (193\%). According to Horkheimer, traditonal theory, be it contemplative metaphysics or positivistic science, hypostatizes an absolute chasm between knowledge and evaluation, thereby ignoring the relativity of epistemological developments with respect to historicaliy conditioned relations of social life. The methodological presuppositions of the exact sciences, he noted, could be linked to the "advance of the bourgeois period," i.e.. to the demand for technically exploitable knowledge in generating ever efficient forces of production." More important, Horkeimer believed that the demand to achieve ever efficient means of prediction and control was only one interest alongside another equally fundamental interest in emancipation, the epjstemic correlate of which was 
reflection." By reflection Horkheimer meant not only the philosophical exanination of the validity and range of particular branches of knowledge, and activity which, in the tradition of Kant and Eichte, disposes of opistemological dogmatism, or the view that the object of kmowledge is "given" independently of the activity of the knowing subject, but also the critical exposure of cultural prejudices which legitimate class domination."

Seeking to establish a legitimating warrant for critical reflection in social life as securely grounded as that possessed by technical knowledge, Horkeimer suggested a number of possible connections, none of which was convincingly defended. The emancipatory interest underlying eritical reflection is not, he insisted, spun out of pure thought. "Insofar as mind seeks autonomy or man's control over his own life... it is able to recognize this same tendency as a force in history." Horkheimer also maintained that "the viewpoint which (Critical Theory) derives from historical analysis as the goals of human activity is immanent in human work." Given Horkeimer's critique of instrumental rationality, this solution seems unsatisfactory. Elsewhere Horkheimer claimed that "this [emancipatory] desire has also found expression in cultural creations." This solution, too, is rendered problematic by Horkheimer's distrust of tradition. The difficulty is only slightly attenuated when Horkheimer says that a "certain concern is also reguired if these tendencies are to be perceived."100 Rejecting Lukács" "identity" thesis that the central position occupied by the proletariat in the process of production enables it to overcome the relfied appearance of social reality and achieve an awareness of its true interests, Horkheimer concluded that "the truth becomes evident in the person of the theoretician."10i This solution seems to entangle Horkheimer in the very idealism which he sought to avoid in the first place.

Despite the privileged role assigned to the critical theoretıcian ill dispensing practical enlightenment, the founders of the Erankfurt school did not feel compelled to justify their interpretations vis-a-vis a systematic ontology. With the exception of Marcuse's early flirtation with Heidegger's fundamental ontology. they adamently opposed "ahistorical" treatments of social life. ${ }^{102}$ This attitude is especially evident in Adorno's critique of Kierkegaard's notion of repetition and simultaneity and Heidegger's doctrine of historicity.

According to Adorno, Kierkegaard's existentialism "does not aim towards the determination of subjectivity. but of ontology."1B" The paradoxical return to idealisin and its identity of subject and object is markedly underscored by kierkegaard's notion of historicity. which emphasizes the timelessness of the past 
in the present. A similar criticism was levelled against Bergson's notion of durée by Horkheimer who charged that the circularity of temporality as the former conceived it absolutized the present.104 Even prior to the compositjon of Negative Dialelstik (1966), indesd, in some of his earliest writings, Adorno criticized Heidegger's notion of historicity as a kind of "natural history" whose ontological roots were firmly embedded in the old identity philosophy of Hegel. In Adorno's opinion, Hej.degger collapses the distinction between subject and object, history as experienced and $r \in a l$ history, etc.. thereby succumbing to positivism. ${ }^{105}$

The denial of absolute truth created certain difficulties for critical Theory. as we have seen, Horkheimer was unclear about the legitimating warrant for ideology critique (unlike Karl Mannheim, he refused to go so far as to categorize Harxism as just another ideology). However, Adorno for one did not hesitate to suggest that Critical Theory's adherence to truth was not entirely consistent with its repudiation of ontology and epistemic absolutism. The inconsistency resides in the fact that the privileged status of those who offer enlightenment to those who have fallen under the sway of 1deology needs to be justified.205 Now it is particularly noteworthy that Habermas' most recent examination of the history of social thought from Weber to Critical Theory emphatically demonstrates the internal connection between neo-Kantian Erkenntnistheorie and Bewusstseins-philosophie on the one side and a subjectivization of practical. reason on the other. In the wake of Critical Theory's failure to mitigate its own "contradiction," a failure which is directly attributable to its inability to break out of meinstream neoKantian thought, Habermas attempt to revive the Hegelian project of grounding the universal in the historical community of speakers carries with it a particularly convincing urgency.107

Gadamer, Heidegger, and Hegel. I indicated earlier that the "old Hegelian tradition provides a good perspective from which to view Gadamer's ontological hermeneutics. This tradition as it has come down to us is essentially theological and conservative. In the context of our present discussion, it is worth bearing in mind some of its major implications for the development of Heideggerian philosophy in general and Gadamer's philosophical hermeneutics in particular.

The tradition recurred to Hegel's Logik as the centerpiece of his system and therefore took seriously his claim that history recapitulates the eternal logos of being. Seen in this light, the histurical dialectic of Geist unfolding 1 taelf in time can only be understood as an identity-process involving the reflection of Geist into itself by way of its estrangement or objec- 
tification in concrete, historical life. The dialectical negation of an historical form of life is at one and the same time its preservation and elevation; or stated in Aristotelian terms, it is the becoming of what it essentially and already implicitly was. Again, for Hegel as well as for Aristotle, to say that the becoming of essence (Wesen) is its having been (Gewesen), is just to say that the identity of a substance is what remains the same throughout its appearances. This notion of historical experience as a process of emergent truth was, mutatis mutandis, taken up by Kierkegaard and passed down to Heidegger where it insinuated itself in his doctrine of historicity and repetition. 20

To a certain extent, the conception of truth outlined above plays a much more decisive role in Gadamer's philosophy than it does in Heidegger's. To understand why this is so reguires an extended examination of the latter's theory of historicity and repetition as it developed out of a confrontation with dialectical theology. It is iny contention that Gadaner's return to Hegel is partially motivated by what he perceived to be a residual trace of neo-Kantian historicism in tinis theory.

In one of his essays, Gadamer reminisces about the profound impact that Hisidegger had upon Marburg theology in the early 1920's.' ${ }^{\prime}$ ' After hearing an address given by the dialectical theologian Edward Thurneyson. Heidegger, who was then an assistant professor at Marburg and Gadamer's mentor, remarked that the true task of theology was to seek the word that is able to call o :e to faith and preserve one in faith. In those days, neo-Kantianism was still very much in vogue at Marburg. Yet Heiregger's statement seemed to capture the sentiments cf a new generation of theologians who were beginning to question the methodological presuppositions of the older school. Above all, it expressed a yearning to return to the religious dimension of human experience, especially the awareness, so pervasive in Augustinian theology, that man cannot reach an understanding of himself by his own means. Given the occasion which promoted the remark, it also seemed, in retrospect, to anticipate many of the dialectical themes concerning language, understanding, and tradition that would come to dominate Heidegger's thought in the years to come.

In order to appreciate the theological strain in Heidegger's hermeneutic philosophy, one must return to the Romantic reaction against the Eulightenment inaugurated by German Idealism and carried forth into the twentieth century by Existentialism. Already Herder's critique of the Enlightenment's teleological view of history and his claim that each culture must be judged on its own terms challenged the power of ahistorical reason to achieve practical insight. let if we accept 
Gadamer's estimate of the counter-Enlightenment, it is Hegel's concept of Geist, rather than Herder's historicistn, which provided the impetus for the critique of abstract rationalism and subjectivism in the twentieth century.110 Hegel's opposition to "external reflection," or raisonnement, as presented in the Phänomenologie is primarily directed against Kant's "law-testing" ethics, which prescribes a method for evaluating customary maxims of action against a purely formal criterion of universalizability. Kant's ethics elevates private conscience, purged of all heteronomous elements, such as traditional prejudices and sensuous inclinations, above the historical substance of society. In Hegel's judgment, however, subjective reflection cannot proceed independently of values which devolve upon it from the public orders of state, family, and culture; for individual personality is itself shaped by publically recognized customs and traditions which precede it absolutely. 121

Hegel's concept of Geist has its theological roots in the Christian concept of pneuma, or the Holy Spirit, which unites everyone in the ego-transcending embrace of agape. The themes of redemption and salvation, so central to kerygmatic interpretations of the New Testament, likewise have their parallel in Hegel's concept of absolute knowledge, which transcends finitude and alienation and culminates in self-certainty.

Søren Kierkegaard rejected the rationalism implicit in Hegel's system while retaining its dialectical structure. According to Kierkegaard, rational reflection is incapable of comprehending the irrecusable finitude and uncertainty of human existence, a theme which was later developed in the twentieth century by Karl Jaspers in his analysis of the limits of objectifying science with respect to boundary situations pertaining e.g., to death and guilt. Kierkegaard argued that man's relation to the absolute was mediated solely by a leap of faith based upori inner conviction. 112 lhis supreme estimatjon of "subjective truth" and decision was also microred in his criticism of the levelling tendencies in modern society--an uncomproinising portrayal of the public which later inspired Heldegger's discussion of inauthenticity in Sein und zeit (1927).113 It may well be, as Gadamer says, that this particular influence, reflected in the latter's "moralizing" tendency to contrast the individualized decisiveness of authentic Dasein with the inauthentic "falleness" of one immersed in the anonymous conformism of the public. rather conceals Heidegger's real intention." 14 Therefore, we shall approach Kierkegaard's contribution to Heidegger's thought from the standpoint of his theory of repetition and simultaneity.

The notions of repetition and simultaneity recall the kerygmatic. transformative power of the logos, or word, which bleidegger alluded to in his remart about 
the call to faith. In Gadamer's opinion, Kierkegaard was the first dialectical theologian. He understood the "call to faith" as the permanence of an authoritative claim which mediates the proclamation of the Gospel with the present. Simultaneity, Gadamer maintains, did not mean for Kierkegaard the annihilation of the believer's finitude and identification with the past, but rather indicated the "formulation of the believer's task of so totally combining one's own presence and the redeeming act of Christ, that the latter is expressed as something present (not as something in the past) and 18 taken seriously as such."118

It would be fair to say that the Christian notion of parousia (absolute presence) that informs Kierkegaard's notior of simultaneity is also exemplary for Heldegger and Gadamer, who regard the act of understanding as the receptive appropriation of a message having ultimate authority for the interpreter and of vital significance to his moral identity. 11 For Gadamer the authority of the message is confirmed in its ageless efficacy; we are already delivered over (Uberliefert) to an event of understanding and truth which happens to us independently of our conscious volition.

Kierkegaard's notion of repetition, which Heidegger later incorporaced into his own theory of historicity. stresses the moment of preservation in understanding.i17. As we have seen, Kierkegaard's notion of simultaneity articulates the element of preservation in kerygmatic interpretation, namely, the becoming-fully-present (parousia) of the Gospel in its historical presentation or proclamation.

The theological motifs implicit in Hegel's ard Kierkegaard's respective philosophies comprise an important part of the counter-Enlightenment legacy bequeathed to Heidegger and Gadamer. The Phenomenological Movement in Germany with which these philosophers are associated also came to question the subjectivistic presuppositions of neo-Kantianism. The theory of intentionality developed by Husserl challenged the subject-object, value-fact distinctions which underlie scientific naturalism. However, despite the fact that Husserl originally conceived his phenomenology as a "rigorous science" which, by "returning to the things themselves," 1 .e.. the unexpurgated residue of pure experience, would combat the absolutist pretensions of natural science to uncritically dictate ontological commitments, it still operated within the subjectivist anbit of neo-Kantianism, attributing the constitution of the meaning of experienced objects to a transcendental ego.11. However, in the last years of his life Husserl himself cam to question the possibility of completing the reduction, or methodological bracketing of prejudices--the definitive characteristic of "scientific" philosoplyy as he understood it. And in 
the posthumous writings contained europäischen Wissenschaften und

in Die Krisis der Phänomenologie (1934-37) he all bie Transzendentale notiol of a transcendental subjectivity cut off from the collective Lebenswelt, or pre-consuious horizon of intentionalities embedded in historical languages, traditions, and habits. 1 '

Heidegger's critique of subjectivism is closely interwoven with his radical redefinition of the problem of truth, which in the context of sein und Zeit is treated as an ontological problem. According to Heidegger, beings are not originally encountered as isolable objects with substantive properties such as color, weight, extension, etc., but are rather disclosed as implements of use, what he calls ready-tohands (Zuhanden). The disclosure of pragmata, which includes such items as tools, equipment, construction materials, etc., is essentially teleological and practical in nature, viz.. their meaning and identity are defined with reference to a totality of assignments and functions, all of wich are referred back to the intentional vector of the agent's aims.120

Heidegger elaborates the holistic nature of experience by designating understanding (Verstehen) as the primary structure of our insertion in the world. Understanding so conceived is neither a subjective faculty of sympathetic concern nor a specific epistemic unethod for deciphering symbolic objectifications, but rather denotes the way in which human beings inhabit a world for stated differently, the way in which a world is openea up to us). For Heidegger, understanding is assigned the status of an ontological "clearing" whereby a world-horizon, or contextual background, is originaliy projected. The anticipatory, protensive orientation of projection (Entwerfen) is analogous to that foresight which guides our reading of a text. In the case of textual comprehension, the meaning of each sentence is syncategorematically determined by situating it within a not-yet-completed sequence of interrelated actions and events which are tied together in a coherent totality by way of an anticipatory completion of the narrative. Similarly, from an ontological perspective specific involvements with persons and entities are thrown into relief against the anticipatory projection of a world-horizon. In both instances there exists a semantic interdependence of part and whole.121

The projection of a world-horizon is not to be construed as an act of purely conscious, volitional discretion. The ontological status of understanding indicates a radical denial of cartesian dualism and the false freedom which it imputes to human agency. Understanding "happens" as a moment of ciarifjcation which has already been elicited, prior to any act of conscious intent, as a response from the deep recesses of our cultural being to possibilities of meanilig sug- 
gested by our present circumstances. Dasein is beingin-the-world, viz., our ontological insertion in a preunderstood world signifies a primordial community of human being and reality which resists reduction to either a realist or an idealist point of view.

The significance of Heidegger's hermeneutic holism for the problem of truth can be grasped once we understand the derivative nature of the proposition. In the pre-propositional circumspective concern (Umsicht) which typifies our sighting of tools, there is no comtemplative detachment separating "subject" from "object"; the implement is inconspicuous and merges with the manipulator. Though it is impossible to piece together the tool from an isolated subject and object, one can tracethe emergence of the "thing," or "presentat-hand," in breakdowns and disruptions within the equipmental network. Once the tool loses its functionality, the unity of the referential Gestalt dissolves and we are left with a lifeless "object" which manifests itself as a potential subject of predicates. The origin of the thing, then, roughly coincides with the possibility of the proposition as that which explicitly predicates properties of an object.122 Once the proposition is further removed from immediately indicating something within our experiential horizon and is reified into a piece isf information for purposes of transmission, it becomes possible to view it as a thing to be compared with an objective state of affaj.rs. Hence, just as "thinghood" is revealed as a limited manner of projecting a scientific, theoretical world which is parasitic on an a priori matrix of practical involvements, so too, Heidegger argues that the correspordence theory of truth is likewise possible only against the background of a more universal experience of truth conceived as "disclosedness" (aletheia)123 Heidegger's analysis of truth as disclosedness is essentially congruent with our commonsensical understanding of the notion. Heidegger asserts that the truth of a proposition manifests itself when it is demonstrated to be true. Such demonstration has nothing to do with comparing proposition with object, but involves providing evidence in support of the proposition, e.g., by pointing out something or by proffering reasoned justification. The fact that the truth of a posposition is a function of its being warranted rather than of its being related in some mysterious way to brute sense data shows that a prior context of discourse determining the semantic domain of reference is already presupposed. The presentation of evidence in support of a proposition, for example, merely singles out those salient aspects of the data that have already been previously located by an agreed upon set of conventional signifiers. In other words, ostensive reference presupposes that the referent already be semantically highlighted, named, and thereby ontologically deter- 
mined vis-à-vis the entire linguistic totality of which the atomic signifiers are but a part. 12 "

I have noted above that for Heidegger understanding is itself ontologically embedded in a prior, culturally determined matrix of presuppositions which delimit the range of possible meaningfulness. This dimension of Heidegger's theory of understanding, which will occupy the remainder of my treatment of his hermeneutic theory, leads directly to a confrontation with the issue of relativism.

According to Heidegger, presuppositions operate below the threshold of conscious intent as a vis a tergo which conprises the familiar referential background guiding our search for possible meaning. This dependence upon a pre-reflective sedimentation of orientations, what Heidegger calls the facticity of human existence, signifies the state of being delivered over to a situation, a mood, a cultural identity etc. 225 Now Heidegger believes that this dependency has ontological import for the way in which human being and world are codeterminative. Projected possibilities which do not facilitate understanding, or in some other way fail to mesh with the horizon of expectations, exert a counterthrust that alters this horizon, and therewith, our self-identity.i2s The reciprocal reinterpi:etation of world and self (Auslegung) which transpir 3 as a result of this critical interplay is fur ther elaborated by Heidegger in his discussion of historicity.

Heidegger's discussion of historicity is primarily concerned with explaining the continuity of Dasein in light of its dispessed, fraginented--literaliyselfless--mode of inauthentic existence. The problem of self-understanding is clarified once we realize that what we are is determined by our choices, even if this means allowing others to define our conduct and expectations. Choice, however, doss not axise ex nihilo. The linguistic forms and traditions that are inculcated in us map out a sort of destiny (Geschick) or predetermined set of future possibilities in terms of which we underetand curselves and our world. Not only is the being of individuals and their world relative to tradition, but this "ontological. circle" is itself modulated through cultural transmission. A cultural heritage is not a static accumulation of anachronisms, but is a dynamic process whereby what is handed down and preserved is necessarily reinterpreted in light of the interests and concerns of the present. 127

The past, then, conditions the range of possible understanding. Even authentic Dasein which has freed itself from public conformism and has taken responsibility for its future must choose its possibilities from collective orientations shared by the community at large. Hence, the continuity of one's identity as an 
event (Geschehen) of cultural transmission is always a Mitgeschehen, a shared event.

In Sein und Zeit Heidegger maintains that every horizon of understanding is equiprimordially a linguistically ramified discourse. In the post-Kehre writings culminating in Heidegger's famous Brief an der Humanismus (1947), the ontological nexus increasingly shifts away from human decision to language viewed as the collective repository of determinate concepts which first make possible the identification and descrimination of meaningful beings and events. Consonant with the theological undertone of this reversal, which assigns to Dasein the passive role of spokesman for languaye, we now find Heidegger advocating, not resolute decisiveness and action, but receptivity (Gelassenheit) and openness (Ofienhe1t) as indispensable conditions for harkening to the call of being. ${ }^{28}$ This respect for the authority of language as the "house of beirig" is combined with a kind of self-abnegating reverence that has much in common with the German mysticism of Meister Eckhart and Angelus Silesius.12s

The aforementioned account of truth clearly has relativistic inplications. If disclosure is structurally defined by an ontological circle in which every interpretation continually discloses new possibilities thereby transcending itself, then understanding and truth will necessarily be partial and incomplete. Consequent.ly, there can be no final, absolute interpretation of reality which escapes revision in view of the open horizon of future projects.

of course, it is undeniable that Heidegger took hinself to be refuting the kind of nihilism and relativism that he tliuught was endemic to historicist historiography.13: The implications of Heidegger's analysis reveal an attempt on his part to salvage a notion of objectivity which draws upon the theologicalheritage discussed above. Citing with approval Count Yorck's criticism of Ranke as ein Grosses okular, Heidegger argues that any attempt to reduce history to a pure description of facts is a perversion of its authentic being."1' Nietrsche's attack on German historiography is presented as an altermate model of historical research. According to Nietzsche, historians who seek to replicate the past without any regard whatsoever for the interests of the present only convey anachronisms that are meaningless to contemporary audiences. True history involves the appropiation of past possibilities whlch critically rebound upon our complacent presumptions. The "monumental" and "critical" inoments of history, however, must also be compleinented by an "antequarian" interest in preserving the critical originality of the past against the levelling tendericies and distortions of contemporary consciousness." 
The kind of objectivity which is required in authentic historiography is elucidated by Heidegger in his discussion of repetition (Wiederholung). The repetition of the possibilities of the past involves a dialogue between the historian and tradition in which anachronistic elements in the latter and distorting prejudices in the former are subject to rejection (Widerruf) in a process of mutual questioning (Erwiderung). IJ Although Heldegger's account of authentic historiography is compatible with standard criteria of validity, such as narrative coherence and objectivity (i.e.. loyalty to the author's intended meuning), it does not provide any decision procedures for adjudicating disagreements between equally compelling, equally coherent accounts of the same event. clearly, the kind of "scientific" truth and objectivity which Heidegger intends to justify has little in common with what has customarily passed for truth and objectivity in the scientific community.

It is in connection with the above problein that Gadamer's transposition of Hegel's dialectic of experience onto Heidegger's notion of historical understanding is best. gauged. Following Hegel's preliminary analysis of experience in the introduction to the Phänumenologie, Gadamer holds that truth and its experience must be regarded as two aspects of the same process. Seen from the angle of experience, historical understanding is a process of cultivation whereby egoistic individuality is elevated to the moral plane of free, universal self-consciousiess. Continuing one's Bildung beyond the narrow purview of one's parochial understanding by fariliarizing oneself with the languages, customs and literary accomplishments of other historical peoples enables one to achieve the freedon or openness necegsary to acquire new experience." "A

Gadamer's notion of effective historical consciousness (Wirkungsgeschichtliches Bewusstsein) denotes a level of understanding that has attained both breadth (universality) and depth (reflexive openness). Contrary to Dilthey's notion of historical consciousness, the freedom from prejudice definitive of Gadamer's conception of hermeneutical consclousness is not actuated by eclipsing one's entive cultural background and restoring it to the pristine state of a tabula rasa.iss Rather, the emancipation from restrictive prejudices coincides with the acquisition of new cultural prejudices; for in Gadamer's opinion, understanding is only possible by translating the familiar into the unfamiliar. Not the transcendence of prejudice, but the disclosure of productive prejudices that open up new possibilities of inquiry is the goal of hermeneutic consciousness.

Such consciousness is not an attitude that can be methodically or voluntarily effected, but is a state of being which one achieves pari passu in the course of 
interpretation itself. Gadamer elaborates upon this process further by introducing two concepts, the fusion of horizons and dialogue, that recall to mind obvious Hegelian analogues. We have touched upon these notions earlier with respect to our discussion of the BettiGadamer debate. It suffices to note that in contrast to Hegel's dialectic of experience, hermeneutic experience as Gadamer conceives it does not culminate in a complete identity of subject and object, but instead issues in progressively higher states of reflexive openness and universality. Significantly, Gadamer argues that openness and mutual recognition are necessary conditions of true dialogue, conditions which he defines by reverting to the normative phraseology of political rights: "The experience of the 'thou' also manifests the paradorical element that something standing over against me asserts its own rights and requires absolute recognition and in that very process is understood."136 Elsewhere Gadamer acknowledges that hermeneutic consciousness articulates the regulative ideal of an unlimited, unconstrained consensus uniting all humanity. As a desideratum, however, the "ideal of a shared life under conditions of uncoercive communication is... just as binding as 1 t is indefinite. Very different lifestyles can be harnassed to this formal framework. "1" The acknowledgement of a counterfactual hermentutic ideal is a significant concession on Gadamer's part, and he irequently defers to it in his criticism of mass media manipulation, again a considerable departure from some of his earlier views:

Both rhetoric and the transmission of scientific knowledge are monological in form; both need the counterbalance of hermeneutical appropriation, which works in the form of dialogue. The chief task of philosophy is to justify this way of reason and defend practical and political reason against the domination of technology based upon science. . . it vindicates again the noblest task of the citizen--decision-making according to one's responsibility. ${ }^{3:}$

The influence of Hegel is also apparent in Gadamer's theory of truth. Like Hegel, Gadamer conceives truth as a process of reflection, or re-presentation in which a universal content, e.g., the experience of human finitude that originally found expression in Greek tragedy, is preserved, extended, and further articulated in historical interpretation. (Gadamer of ten uses such expressions as "ideality." "contenporaneity," "the classical." etc.. to get at the historical nature of such "concrete universals"). Again, Gadamer's retrieval of artistic truth from the subjectivism and formalism of Kant's aestlietics shows that in art the very play-structure of experience itself finds exem- 
plary expression. Einally, Gadamer concurs with Hagel in holding that truth reveals itself ex post facto, from the vantage point of a retrospective comprehension of the totality of past interpretations. Temporal distance, far from being an obstacle to understanding, is rather the necessary precondition for critical dialogue. 130

The other foundation of the hermeneutic experience is language itself. Gadamer's conception of the "speculative" nature of language as a truly reflexive, infinite repository of meaning capable of expressing everything harks back to Hegel's notion of a speculative proposition. For Hegel, speculative propositions that ascribe essential predicates to subject terms are synthetic a priori, and therefore simultaneously assert a relationship of identity and difference between two terms. Language also possesses a speculative nature insofar as its inherent reflexivity (which Gadamer illustrates by referring to Plato's use of light as a metaphor for the beautiful) enables it to mediate the various antipodes of experience: universal and particular, is and ought, etc. In the final analysis, Gadamer attempts to circumvent the problem of historicism by appropriating precisely that metaphysical tradition coalescing around Hegel and Plato that Heidegger seeks to overcome.

\section{VI}

In summation, we noted at the outset of our historical analysis that Gadamer. and Habermas share a common antipathy towird the neo-Kantian description/evaluation distinction along with its attendant positivistic annexation of the episternological achievement of the human sciences to the methodological paradigm of the cxact sciences. The source of this bifurcation of experience, they believe, resides in the subjectivistic reduction of understanding to psychological Nacherleben. symptomatic of which is the methodological truncation of the protblem of understanding itself. In order to rectify this mistaken conception of understanding, Gadamer and Habermas undertake a deeper philosophical reflection which not only discloses the intersubjective, communicative structure of understanding, but also reveals how communicative understanding, so construed, is itself transcendentally constitutive of society, making possible cultural reproduction (the transmission of language, knowledge, and culture generally), social integration (the securing of a normatively based social solidarity), and socialization (the formation of individual and social identity). Gadamer's theory of the prejudice structure of human understanding and habermas' theory of the interest. structure underlying human knowledge both attest to the value-laden nature of all experience, whether it be the 
objectifying experience of the exact sciences or the participatory hermeneutic experience of the Geisteswissenschaften.

The philosophical bias of Gadamer's and Habermas' "methodological" critique of neo-Kantianism can be traced back to their recovery of Hegel, especially his objections against Kantian subjectivism and his conception of the linguistic, dialectical nature of experience. In both cases, the return to Hegel enabled these philosophers to resolve fundamental conundrums within theiv respective philosophical traditions that derived from remnants of a déclassé neo-Kantianism.

Gadamer's appropriation of the conservative, theological and speculative tradition of. Hegelian thought is summed-up in the claim to universulity which he makes on behalf of the hermeneutic phenomenon. The clain to universality of hermeneutic experience affirms the primacy of logos, or language, as the fundamental vehicle of truth and meaningful being. The paratactic juxtaposition of truth and method, as well as other philosophical antinomies, are resolved in the unitary solvent of language, conceived as a universal, unlimited process of dialogue. The Sprachlichkeit, or linguisticality, of human understanding entails that all ontological, axiological, and epistemological regions of experience, be they scientific, rhetorical, poetical, or instrumental, ultimately have their u.uicary ground in ordinary linguistic communication, which mediates the self-understanding of each and every activity, including the application of ull knowledge whatsoever. The speculative nature of this syntinetic achievement also requires the aff: rmation of the differences within it, though like a true Hegelian Gadamer invariably returns to the "dialogue which we are" as the alpha and omega of all tiuth; for him, every disagreement or difference presupposes a prior ground of agreement.

The claim to hermeneutic universality has farreaching implications for Gadamer's conception of philosophical reflection. In Wahrheit und Methode Gadamer identified philosophical reflection with historical understanding, the paradigms of which, he believes, are classical philology, jurisprudence, and theology. As he elsewhere states, the underlying interest guiding the Geisteswissenschaften is essentially conservative: these disciplines serve to recollect and thereby preserve and extend the validity of a timeless truth. ${ }^{\prime \prime}$ This deference to tradition as authority is another indication of the fact that reason for Gadamer is always "present" as a "becoming" that has "already been."

Conversely, Habermas' retrieval of the young, and admittedly Kantian, Hegel prohibits him from assenting to the universality of the hermeneutic phenomenon; for him language acquires the status of being but one of 
the fundamental media of experience (the moralpractical), the other being labor (the cognitiveinstrumental). This distinction can be found, albeit confusedly, in Marx's distinction between relations and forces of production, the two variables of social evolution. In Erkenntnis und Interesse this dichotomy was further elaborated in terms of a distinction between communication and labor. Habermas' later venture reiterates the distinction once again as a difference between two planes of social life, the social 1 ifeworld and the systein of material reproduction. Now the limitation of the field of communicative understanding cannot but have methodological repercussions. Given the inpact of systemic constraints on communication, the structure of rational dialogue must be regarded as an anticipated but nonetheless counterfactual ideal. The postulation by Habermas and Wolfhart Pannenberg of an anticipated completion or perfection of understanding (Gadaner's Vorgriff auf Vollkommenheit) as the telog of a universal history not surprisingly brought upon them recriminations from Gadamer litinself to the effect that such an immediately practical application of his principle constituted a foreclosure of hermeneutic experience à la Hegel.141 In any case, Habermas denied that philosophy can model itself on the Geisteswissenschaften. Prior to his inter distinction between rational reconstruction and social critique, Habermas held that philosophy had to becone social theory in the direct sense of ideology critique, thereby incorporating a functionalistic explanatory moment in its understanding of the "latent," subliminal meaning of historical life.

Despite the apparent irreconcilability of philosophical hermeneutics and critical. Theory, it can be shown, and indeed has been repeatedly demonstrated, that notwithstanding obvious differences between them, the two positions are basically complementary. As I mentioned at the beginning of this essay, my intention has not been to canvass the entire territory covered by the debate but to indicate a possible rapprochement on the basis of their common Hegelian affiliations. It should be apparent by now why I chose the historical path that I did as the most perspicuous and advantageous way of grasping this complementarity. Rüiger Bubner remarked some time ago that one could understand Gadamer's and Habermas' antithetical positions in view of their articulation of different aspects of Hegel's concept of dialectic and reflectior. ${ }^{142}$ When seen from this perspective the complementarity of their respective ontological and counterfactual conceptions of practical reason is also illuminated. For Hecjel as for Gadamer and Habermas, every dialectical sublation is both a critique of an irrational form of consciousness, as well as its validating preservation. There is certainly ample testimony by the interlocutors themselves 
to support this reading of the controversy and therefore I shall not belabor this point any further. Suffice it to say, Gadamer has emphatically stated that he does not oppose truth to method or ideology critique to hermeneutic preservation, and Habermas for his part has made it abundantly clear that scientific reflection cannot transcend the cultural linguistic lifeworld to which it belongs and that ideology critique is itself a re-appropriation of emancipatory possibilities inherent in tradition.

In spite of the above reconciliation, the problem concerning precisely what the differences are between these philosophers still persists. I believe the solution to this problem is to be found by elucidating the senses in which Gadamer and Habermas, despite the best of intentions, have not entirely eradicated neo-Kantian residues from theif thinking. In the remainder of this essay I propose to defend the thesis that Gadawer's philosophical hermeneutics and Habermas' Critical Theory fall on different sides of the neo-Kantian dualism of description and evaluation respectively.

As Ricoeur astutely notes in a recent essay, 13 Gadamer has the appearance of being an unrepentant dogmatist because he limits the epistemological concern yis-à-vis the possibility of critical, "scientific" understanding to a prior ontological reflection on the universality of language. Insofar as Gadamer maintains that the possibility of every understanding presupposes a prior accord, he like Hegel reduces the critical moment of temporal distance to the status of a mere appearance. Wi thout difference, however, chere can be no understanding, a fact which he himself admits when, for example, he acknowledges in his own way the importance-recently emphasized above all in the philosophy of Derrida--of the distancing effect (differance) implicit in all writing and even in spoken discourse, to the extent that the latter also manifests a contexttranscending telos. And, as he and Habermas both emphasize, this critical difference becomes all the more decisive with the advent of historical consciousness and its relativization of tradition. Nevertheless, his insistence upon the ontological belongingness (Zugehörigkeit) of understanding to a unified totality (Hegel's identity thesis) leads him to neglect the role of explanatory methods in interpretation. Indeed, on his dialogical model of interpretation, which he appears to proffer as a methodological prescription as nuch as an ontological description, the only fundamental difference separating the critical interpretation of the skilled hermeneut from the najve, uncritical appropriation of tradition by the untrained lay reader is experience. Moreover, the recollective orientation of hermeneutical reflection as Gadaner conceives it restricts its scope to the modest task of phenomenological description: "My real concern," Gadamer incones, "was 
and is philosophic: not what we do or what we ought to do, but what happens to us over and above our wanting and doing." In view of assertions such as this, it is no wonder that Habermas accuses Gadamer of harboring a positivistic neo-Kantian bias.

In all fairness to Gadamer, however, it must be conceded that in spite of the proclaimed intent of philosophical hermeneutics his own program carries him far from ontological description to moral prescription. This is especially evident in his more recent social and political commentary in which he adverts to the notion of an unlimited community of unconstrained dialogue as a regulative ideal.

Ironicaliy, the latter ldeal, which plays such a prominent role in both Gadamer's and Habermas' respective philosophies is interpreted by them in a peculiar, neo-Kantian fashiou (though Gadamer, as we have seen, is hardly consistent on this matter). If Gadamer can be said to be guilty of a neo-Kantian taint of a positivistic nature, then Habermas can be accused of the same from the standpoint of his formalistlc treatment of practical reason. The quasi-transcendental grounding of practical reason in the ideal speech situation is purchased at the cost of depriving it of any substantive, prescriptive force. The net result is that particular, substantive interests and motives remain unturched (or undetermined as Hegel would say) and therefore are vulnerable to decisionistic treatment.

I would like to follow up this last remark with one final comment about the convergence of Gadamer's and Habermas' respective philosophies. Since their debate, Haberinas has been reluctant to continue advancing the ideal speech situation as a carte blanche warrent for criticizing every de facto consensus. Having apparently taken Gadamer's objections to heart, especially those, which exposed the paradoxical if not selfdefeating status of his communicative ideal, Habermas has retreated from some of the stronger claims he formerly made about the critical scope of the ideal speech situatior. " " In a recent anthology of critical essays devoted to his philosophy and also in his latest study, Habermas has been inclined to follow the advice of his colleague, August hellmer, and regard the ideal speech situation as specifying purely formal rules of procedural justice whose critical function is limited to examining the legitimacy of particular normative institutions. As, such, its use cannot be extended to include the evaluation of society as a whole.ins Even the claims formerly made on behalf of ideology critique are considerably toned down and the program cuncentrating on psychotherapeutic sociology seems to have receded into the background. What remains, curiously, is a social theory whose critical thrust is aimed almost exc]usively at the instrumental "colonialization" of the lifeworld. The latter consists in the 
progressive replacement of communication by strategic steering-media such as money and power which integrate action in accordance with the functional, adaptive imperatives of the economic and state administrative subsystems. Thus, the new criterion of social rationality revolves, surprisingly, around precisely the sort of valetudinarian considerations concerning the maintenance of social equilibrium that has by and large dominated Gadamer's thinking as well.

\section{NOTES}

'See J. Habermas, "Aspects of the Rationality of Action" and H-G. Gadamer, "Historical Transformation of Reason," in Rationality Today, ed. F. Geraets, (Ottawa, 1979).

2P. Ricoeur, "Ethics and Culture," Philosophy Today, 17 (Summer, 1973).

'A. Wellmer, Critical Theory of Society, (New York, 1975), p. 44 .

"D. Misgeld, "Critical Theory and Hecmeneutics," in Critical Theury, ed. by J. O'Neill. (New York, 1976), and T. Kisiel. "Ideology Critique and Phenomenology," in Philosophy Today, 14 (1970).

'See T. McCarthy, The Critical Theory of Jürgen Habermas, (Cambridge, 1978) pp. 187-93; A. Giddens, "Haberimas" Critique of Hermeneutics," Studies in Social and Political Theory, ed. A. Giddens, (London, 1979): R. Bubner, "Theory and Practice in Light of the Hermeneutic-Criticist Controversy" Cultural Hermeneutics, 2 (1975): P. Ricoeur, "Hermeneutics and the Critique of Ideology," in Hermeneutics and the Human Sciences, ed. J. B. Thompson, (Chicago, 1982); D. Misgeld, "Discourse and Conversation: The Theory of Communicative Competence and Hermeneutics in Light of the Debate Between Habermas and Gadamer, "Cultural Hermeneutics, 4 (1977); D. Böhler. "Philosophische Hermeneutik und hermeneutische Methode," in Texi und Applikation, ed. M. Fuhrmann (München, 1981); $\mathbf{T}$. Kisiel, "Habermas' Purge of Pure Theory: Critical Theory without Ontology." in Human studies I (1978); J. Mendelsohn, "The Habermas-Gadaner Debate," New German Critique, 18 (1979): R. S. Gall. "Between Tradition and Critique: The Gadainer-Habermas Debate," in Auslegung, V. 8, No. 1 (Winter 1981); A. R. How, "Dialogue as Product of Limitation in Social Theory,": The 
Habermas-Gadamer Debate," The Journal of the British Society for Phenomenology, V. II, No. 2 (May, 1980).

"H-G. Gadamer, "The Scope and Eunction of Hermeneutical Reflection," in Philosophical Hermeneutics, ed. D. Linge, (Berkeley, 1976), p. 32.

'H-G. Gadamer, "Replik," Hermeneutik und Ideologiekritik, ed. K-O. Apel, (Erankfurt, 1971), pp. 314-17.

"H-G. Gadamer, "Uber die Planung der Zukunft," Kleine Schriften I (Tübingen, 1967), pp. 172-74.

'H-G. Gadamer, "Scope and Eunction," p. 40-41.

$10 \mathrm{~J}$. Habermas, Knowledge and Human Interests, trans. J. Shapiro, (Boston, 1971), Pp. 314ff. The "ontological illusion" mentioned by Habermas indicates the hypostatization of norms having a fixed, selfcontained status, which is held to be indeperident of histoicical conditions. Gadamer's ontological concep. tion of uriderstanding, however, refers to the coconsticuive relationship which obtains between interpreter and rradition. Whether his peculiar interpretation of this relationship also involves the kind of ontological illusion that Habermas says it does is a question which this essay intends to address.

"See J. Habermas, "Toward a Theory of "Communicative Competence," Inquiry, 13 (1970): "Vorbereitende Bemerkungen einer Theorie der kommunikativen Kotnpetenz." in Theorie der Gesellschaft oder Sozial-Technologie, co-authored with N. Luhmann, (Frankfurt, 1871); and "Wahrheitstheorien," in Wirklichkeit und Reflexion: Eestschrift für Walter Schulz, ed. H. Eahrenbach, (Pfülíngen, 1973).

${ }^{12} \mathrm{C}$. P. Snow. The Two Cultures and a Second Look, (New York, 1964).

'H. Marrou, A History of Education in Antiquity, (New York, 1956), Part I Chapters 5-7, Part II, Chapter 1 .

and Ethics, $1180 \mathrm{~b}-1181 \mathrm{~b}$.

"Aristotle, Politics, 1264a, 1269a, 1323b, 1329b,

"See $W$. Woodward, studies in Education During the Age of the Renaissance: 1400-1600, (New York, 1967), Chapter 7, and Vittorino da Eeltre, (New York, 1963), pp. 93-133.

16E. Bacon, New Organon, ed. by $S$. Warhaft in Bacon: Selections, (New York, 1965), pp. 335-44. 
"'E. Bacon, De Dignitate et Augmentis Scientiarum Libri IX, (loc. cit.). pp. 394-416.

"Ibid., pp. 411-16. Hobbes repeats Bacon's critique of the four idols almost verbatum in the first five chapters of the Leviathan. Despite his close association with Bacon, he came to espouse the deductive method of Galileo.

${ }^{29} \mathrm{~K}$. Descartes, Meditations I and II.

$2{ }^{\circ}$ See Anthony Earl of Shaftesbury, Characteristics, (Gloucester, MA, 1963), Vol. 1, pp. 55, 70, 88, and 97 .

${ }^{2} \mathrm{G}$. Vico, On the Study Methods of our Time, trans. E. Gianturco, (New York, 1965), p. 19 .

22 Ibid., p. 23.

${ }^{2} G$. Vico, The New Science of Giambattista Vico, trans. T. G. Bergin and M. H. Fisch (Cornell, 1970), pp. 56-63.

2"Ibid., p. 22, 51 .

${ }^{2 s}$ See H. Helmoltz, Vorträge und Reden, 4th É.. Vol. I. "Über das Verhältnis der Naturwissenschaften zur Gesammtheit der Wissenschaften," pp. $167 \mathrm{ff}$ and $W$. Dilthey. Einleltung in die Geisteswissenschaften in Gesamielte Schriften (stuttgart, 1913-18), Vol. I. Contrary to Erich Rothacker's claim that the expression "Geisteswissenschaften" first appeared in the Schiel translation (Logik und systematik der Geisteswissenschaften (München, 1965), p. 6) R. Makkreel notes (Dilthey: Philosopher of the Human Studies (Plinceton, 1975). p. 36) that the expression was first used by Droysen in the preface to his Grundriss der Historik (1843), which, ironically, was edited by Rothacker himself in 1925 (Halle, p. 97). Prior to Droysen's novel use of the expression, the term Geistwissenschaft was used by Hegelians to refer to the metaphysical science of spirit.

25 See K. Menger, Untersuchungen über die Methode der Sozialwissenschaften und der politisclien okonomie insbesondere (Leipzig, 1883); G. Schmoller "Zur Methodologie der Staats- und Sozialwissenschaften," in Schmoller's Jahrbuch, 1883; and G. Ritzel, Schmoller versus Menger: Eine Analyse des Methodenstreits im Hinblick auf den Historismus in der Nationalökonomie. (Erankfurt, $19 \overline{50}$.

2 'M. Weber, Theory of Social and Economic Organization, ed. T. Parsons, (New York, 1947), Pp. $\frac{\text { 99- }}{\text { Pond }}$ 100 . 
2 "See T. Abel, "The Operation called 'Verstehen'," in $H$. Feigl and $M$. Brodbeck (Eds.), Readings in the Philosophy of Science (New York, 1953), Pp. 677-88.

${ }^{2} \mathrm{M}$. Weber, Economy and Society (New York, 1968), Vol. I, pp. 4-25.

30Ibid., p. 5 .

"Recently, Winch (The Idea of a Social Science (London, 1967)) and MacIntyre ("A Mistake About Causality in the Social Sciences," in Philosophy. Politics, and society, ed. W. Runciman (Oxford, 1964); have both argued that sociological causal explanations are radically unlike causal explanations in the natural sciences. According to Macintyre, to explain an action is to show that it is an instance of following a universally recognized rule (p. 57). Winch develops this linguistic thesis further, arguing that social uniformities establish logical rather than causal relations between sequential actions. Unlike nomological explanations in natural science, logical accounts cannot be deployed for predictive purposes, for instances in which a rule is broken do not have the strength of falsifying data. The notion of explanation developed here, conceived as "understanding the rationale" of an action (i.e., explicating the logical grammar to which it conforms) may be contrasted to Weber's nomological version of explanatory understanding (p. 92). Indeed, on Wincli's model the problem of explaining action in terms of laws cornecting motives and behavior is simply replaced by linguistic analysis (p. 66). Also, see C. Warriner, "Social Action, Behavior, and Verstehen," in Subjective Understanding and the Social sciences, ed.

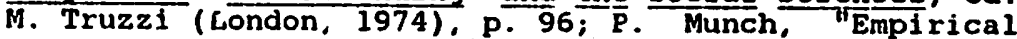
Social Science and Weber's Verstehende Soziologie." p. 62 ; and $M$. Wax, "On Misunderstanding Verstehen: A Reply to Abel," pp. 74-75, for non-psychologistic interpretations of simnverstehen.

${ }^{32} \mathrm{~W}$. Windelband, "Geschichte und Naturwissenschaft," in Fräludien (Tübingen, 1915). Vol. II, p. 144.

"W. Dilthey, (loc. cit.), pp. 36-37.

"W. Windelband, (loc. cit.), p. 145.

${ }^{38} \mathrm{H}$. Rickert, Kulturwissenschaft und Naturvissenschaft (Tübingen, 1899), p. 137 .

'M. Weber, Gesanmelte Aufsätze zur Wissenschaftslehre, 3rd ed. (Tübingen, 1968), p. 603 . 
'To what extent Dilthey and the later Husserl can be classified as neo-Kantians is problematic, since both of them came to disavow the fact/value distinction. For a thorough study of the relationship between Dilthey and the Baden school which portrays Dilthey as a staunch opponent of neo-Kantianism, see R. Makkreel, (loc. cit.), especially Chapter 1 .

"E. Bett1, "Hermeneutics as the General Methodology of the Geisteswissenschaften," in Contemporary Hermeneutics, ed. J. Bleicher (London, 1978), p. 84.

${ }^{39} \mathrm{E}$. Betti. Allgemeine Auslegunslehre als Methodik der Geisteswissenschaften (Tübingen, 1967), pp. 42$\overline{111 .}$

"Ibid., p. 36 .

"E. Betti, "Hermeneutics as General Methodology," (loc. cit.), pp. 56-64.

${ }^{42}$ Ibid. , pp. 64-69.

'Ibid. pp. 62-63.

"E. Setti, Allgemaine Auslegungslehre, (luc. cit.). pp. 282-307, $448-67$.

"In Gadamer's opinion, the demand to understand what the author intended "in his own sense" does not mean "as he intended it," viz.. interpreting the text in such a way that it accords with the original psychological thought processes of the author is not always faitiful to the ineaning of the text as it was originally intended ("Philosophical Eoundations of the Twentieth Century," in Ehilosophical Hermeneutics. (loc. cit.), p. 122.)

"H-G. Gadamer, Truth and Method (hereafter referred to as TM). (New York, 1975), pp. 464-66.

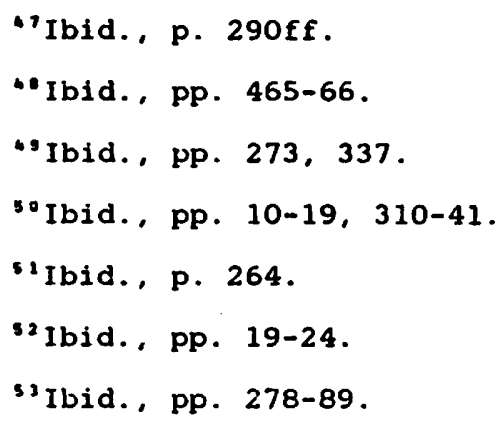


"E. Betti, "Hermeneutics as General Methodology," (loc. cit.), p. 79 .

${ }^{35} \mathrm{E}$. D. Hirsch, Jr., Validity in Interpretation (New Haven, 1979), p. 46. For further discussion of the Gadamer-Hirsch debate see C. E. Arthur, "Gadamer and Hirsch: The Canonical Work and the Interpreter's Interpretation," Cultural Hermeneutics, 4 (1977), pp. $183-97$.

SE. Betti, "Hermeneutics as General Methodology," (loc. cit.), pp. 80-84.

'TK-0. Apel, Transformation der Philosophie, Vol. I (Erankfurt, 1973), pp. 14-17.

s"K. Fopper, The Poverty of Historicism (New York, 1957). pp. 42-45, 58-71, and $7 \overline{6}$.

${ }^{\circ} \mathrm{K}$. Popper, Objective Knowledge (Oxford, 1972), pp. $345-46$.

"K. Popper, "The Logic of the Social Sciences," in The Positivist Dispute in German Sociology, trans. and ed. G. Adey and D. E'risby, (New Yorik, 1976), pp. 95-97.

'K. Popper, The Poverty of Historicism, (loc. cit.). p. 64 .

${ }^{2} \mathrm{~K}$. Popper, The Open Society and its Enemies, (Princeton, 1971), pp. 221-23.

pp. 102-103.

"'K. Popper, "The Logic of the Social Sciences,"

"Ibid., pp. 95-97, 103-04.

"5. Habermas, "A Positivistically Bisected Rationality," (loc. cit.), p. 198 and "Analytical Theory of Science and Dialectics," (loc. cit.), p. 141.

"Glians Albert accuses Habermas of collapsing the distinction between facts and values altogether ("The Myth of Total Reason," (10c. cit.), p. 197). On the contrary. Habermas maintains that the distinction is a valid one for the exact sciences at the level of methodology. The distinction, however, obtains neither at the transcendental level nor at the level of theory formation (see "Eine Polemik: Gegen einen positivistisch halbierten Rationalismus," in Zur Logik der Sozialwissenschaften, (Erankfurt, 1967), pp. $59-\overline{64}$. Popper hilmself concurs with this assessment, though he continues to distinguish purely scientific values such as simplicity, economy, and efficiency from "extrascientific" values, which properly have no role in 
theoretical discourse (see "The Logic of the Social Sciences," p. 97). 35 .

'T. Adorno, "Introduction," (10c. cit.), pp. 34-

"J. Habermas, "Eine Polemik," pp. 59-70.

"J. Habermas, "Nachtrag zu Einer Kontroverse," in Zur Logik der Sozialwissenschaften, (loc. cit.), p. 21.

"Ibid., p. 35.

TIbid.

${ }^{72} \mathrm{H}-\mathrm{G}$. Gadamer, TM, pp. xvi and 465.

"See A. Wellmer, Critical Theory of Society, (New York, 1975), p. 44. According to Welliner, the method of critical reflection advanced by Gadamer is essentially "attenuated" and seeks to "rehabilitate" tradition and authority in a way that reacts against the emancipatory legacy of the Enlightenment.

7"K. Löweth, From Hegel to Nietzsche, (Garden City, N.Y., 1967), p. 67.

"Ibid., pp. 50-58. See K. Rosenkranz, Neue Studien (Leipzig, 1875), Vol. I, pp. 413-64, 548ff.

"Ibid. pp. j6-62. See R. Haym, Hegel und seine Zeit, (Berlin, 1857).

'TM, p. 446.

"See K. Marx, "Letters to Ruge," MEGA, Vol. I, (Berlin, 1927), pp. 573-75; "The Leading Article of the Kölnische Zeitung," (loc. cit.), p. 248; "Introduction to a Critique of Hegel's Philosophy of Law," (10c. cit.). p. 608; "On the Jewish Question," (loc. cit.), p. 584; "Cricique of Hegel's Philosophy of the state," (loc. cit.), p. 406. For further discussion of the young Hegelians see $S$. Hook, Erom Hegel to Marx. (Ann Arbor, 1950).

"J. Habermas, "Arbeic und Interaktion: Bemerkungen zu Hegels Jeneser Philosophie des Geistes," in Tecinnik und Wissenschaft als Ideologie, (Erankfurt, $1968)$.

$\because \mathrm{J} \mathrm{Habermas,} \mathrm{Erkenntnis} \mathrm{und} \mathrm{Interesse,} \mathrm{(hereafter}$ EI) (Erankfurt, 1968), pp. 36-86.

"Arbeit und Unteraktion," (loc. cit.), p. 17-19. 
12 EI, P. 78.

'Ibid., pp. 253-62.

"See J. Shapiro, "The slime of History,"in Critical Theory, ed. J. O'Neill, (New York, 1976), pp. $145-63$.

"K. Marx, "Paris Manuscripts," in Erühe Schriften, pp. 566-69, and Capital, (Moscow), Vol. 1, pp. 79-80. For a defense of the continuity of the humanistic Marx of the Manuscripts and the later Marx, see $S$. Avineri, The Social and political Thought of Karl Marx, (Cambridge, 1968), p. 93 .

"K. Marx, "Inaugural Address," in Selected Works, (Moscow, 1962). Vol. I, p. 40 and "Letter to Bolte," Nov. 23, 1871, in Marx/Engels Selected Correspondence. (Moscuw, 1955), p. $253 \mathrm{ff}$.

' $K$. Marx, A Contribution to a Critique of Political Economy, ed. M. Dobb, (New York, 1970), pp. 20-21. Also see Engels' letter to Bloch, sept. 21-22, 1890, Selected Correspondence, p. 394.

"K. Marx and E. Engels, The German Ideology. Marx/Engels Collected Works, 1976, Vol. 5, pp. 28-32, 57-62 and Capital. vol. I, (1oc. cit.), pp. 76-87. According to Marx and Engels. ideology is the inversion of thought and reality or ab itract and concrete. Hegel commits the error of conceiving the concrete as the product of a dialectic of abstract categories. This leads him to see reality as thought, thereby hypostatizing the historical as something unchanging, $i . \in$. as falling under the purview of a purely logical or ontological process. Eetishism is ideology which proceeds in the reverse direction. It construes consciously constituted (and therefore historical) social reality as something purely ratural and thence proceeds to adduce the immutable abstract laws of the market from what are actually concrete modes of social interaction. For a discussion of the relationship between Marx's theory of ideology and his theory of fetishism see $s$. Moore, The Critique of Capitalist Democracy, (New York, 1957), Cliapter 3 . 1936.

"See Studien über Autorität und Famile, Paris,

"In the words of Adorno and Horkheimer, "when the public sphere has reached a state in which thought inescapably becomes a commodity which speech inevitably promotes, then the atteinpr to get belind such depravity must refuse allegiance to established requirements of 
speech and thought" (Dialectic of the Enilightenment, trans. E. Cummings, (New York, 1950), pp. xi-xii.)

'M. Weber Die Protestantische Ethik, Köln, Bd. 1, 1973. pp. 187-89.

22 Ibid.

"Eor a good discussion of the Marx-Lukács connection, see A. Eeenberg, Lukács, Marx, and the Sources of Critical Theory, (Totowa, NJ, 1981) and my review of the same in Man and World, no. 16 (1983), pp. 72-77.

"M. Horkheimer, "Traditional and Critical Theory," in Critical Theory. trans. J. O'Connel, (New York, 1972). p. 210 .

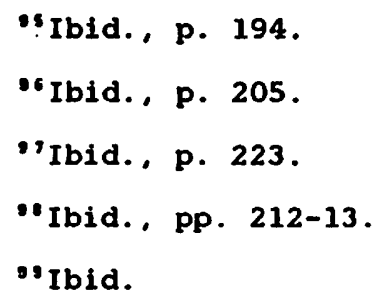
Philosophische Hefte, 1 (1928), "Das Problem der geschichtlichen "Wirklichkeit," in Die Gesellschaft, VII, 4. (April, 1931), and Hege I's Ontologie und die Grundlegung einer Theorie der Geschichtlichkeit, (Erankfurt, 1932). Marcuse was primarily responsible for introducing phenomenological categories to the Institure. While at Ereiburg, the young Marxist was impressed by Heidegger's Sein und Zeit and its emphasis on historicity, concern (sorge), and resoluteness (Entschlossenleit), all of which point to the centrality of praxis as an ontological category. Unlike Adorno and Horkheimer, Marcuse was to retain a fundamental interest in ontology. See Marcuse's defense of Marx's philosophical anthropology in "Neue Quellen Zur Crundlegung des historischen Macerialismus," Die Gesellschaft, IX, 8 (1932).

$103 \mathrm{q}$. Adorno, Kierkegaard: Konstruktion des Aesthetiscnen, (Tübingen, 1933), p. 46 . 
10"See M. Horkheimer, "Zu Bergson's Metaphysik der Zeit," in zeitschrift für Sozialforschung, III, 3 (1934).

${ }^{105}$ See T. Adorno, "Die Idee der Naturgeschichte," in Gesammel te Schriften, Bd. 1, (Erankfurt, 1973), pp. 351-53.

${ }^{105}$ T. Adorno, Eingriffe, (Erankfurt, 1963), p. 14.

10 'See J. Habermas, Theorie des kommunikativen Handelng (hereafter TKH). (Frankfurt, 1981), PP. 461533 .

10:See my forthcoming article in Kantstudien, "Hegel on Leibniz and Individuatiou."

109 H-G. Gadamer, "Martin Heidegger and Marburg Theology." in Philosophical Hermeneutics, pp. 198-212.

$110 \mathrm{H}-\mathrm{G}$. Gadamer, "The Philosophical Foundations of the Twentieth Century," in Philosophical Hermeneutics. pp. 110-14.

${ }^{11}$ See G. W. F. Hegel, Phänomenologie des Geistes, 2nd ed. (Erankfurt: Ulstein, 1973), pp. 327-74.

$112 \mathrm{~s}$. Kierkegaard, Concluding Unscientific Postscript, trans. D. Swenson and $w$. Lowrie, (Princeton, 1941), Chapter 2, and Fear and Trembling, trans. W. Lowrie, (Princeton, 1941), pp. 53, 64-91.

11'S. Kierkeggard, The Present Age, trans. A. Dru, (New York, 1902). 1.25 .

1"H-G. Gadamer, "Philosophical Eoundations," p.

${ }^{115} \mathrm{TH}, \mathrm{pp} .112-13$.

$116 \mathrm{~s}$. Kierkegaard, Philosophical Eragments, trans. D. Swenson, (Pririceton, 1936), Chapter 4.

${ }^{137} \mathrm{~S}$. Kierkegaard, Journals and Papers, trans. Howard and Edna Hong, (Bloomington, 1970), Vol, II, p. 1569. Kierkegaard criticizes Hegel's dialectic as a process in which succeeding stages totally negate their predecessors "as a ligher tjtle or rank swallows up a lower title."

"'E. Husserl, Ideas, trans. W. R. B. Gibson, (London, 1931).

$113 \mathrm{H}-\mathrm{G}$. Gadamer, "The Science of the Lifeworld," in philosophical Hermensutics, pp. 182-97 and "The 
Phenomenological Movement" in Philosophical Hermeneutics. pp. 130-81. Contrary to Oskar Becker and Ludwig Landgrebe, who maintain that the Krisis reflects a predominantly Heideggerian existentialist influence, Gadamer argues that the later Husserl repudiated neither the ideal of philosnphy as a rigorous science nor the ultimacy of the transcendental ego. As Gadamer rightly points out, these notions are not easily harmonized with Husserl's treatment of the historicality of the Lebenswelt.

$1{ }^{\circ} \mathrm{M}$. Heidegger, Being and Time, trans. E. Robinson and J. Mauguarrie, (New York, 1962), pp. 96-102.

121 Ibid. , pp. 182-88.

222 Ibid., pp. 102-07, 189-203. Although practical "know how" does not get articulated in the mind in the form of explicit propositions--a point that is eloquently defended in G. Ryle's the Concept of Mind, (New York, 1949), pp. 25-61--the manner in which language haunts thought and behavior need not be explicitly propositional or mental in the ordinary sense of these terins. Both Gadamer and Habermas embrace the logical connection between language, behavior, and thought that is captured by Ludwig Wittgenstein's notion of the language galle as a "form of life."

${ }^{123}$ Ibid., pp. 114-24, 264-93. There has been much controversy generated by Heidegger's etymological derivation of the Greek term aletheia. Paul Friedländer for one argues that the term originally meant correctness rather than disclosedness. See "Eriedländer vs. Heidegger: The Aletheia controversy," by C. S. Nwodo in The Journal of the British Society for Phenomenology, $2(1979)$.

12"Ibid., pp. 261, 169-73. See G. Schufrieder. "Art and the Problem of Truth," in Man and World, 13 (1980), for a discussion of the different levels of truth in the Heideggerian corpus. According to Schufrieder, one may distinguish 1) truth as a relationship of correspondence from 2) ontic truth as that which discloses phenomena as confirming evidence. The latcer, in turn, must be distinguished from 3 ) ontological truth conceived as that which originally discloses being in general. The distinction between ontic and ontological truth was only fully worked out for the first time in Heidegger' \& Des Ursprung des Kunstwerkes.

$$
123 \text { Ibid., pp. 174, 435-36. }
$$

126 Ibid., p. 192. For Heidegger, understanding is interpretation because our preunderstood assumptions are engaged at every encounter, albeit for the inust 
part preconsciously. The more frustrated our expectations are, the more explicit and methodical our reflection.

${ }^{127}$ Ibid., pp. 435-36.

12 'See Unterwegs zur Sprache (Pfüllingen, 1959); Gelassenheit. (Pfüllingen, 1959): Brief an der Humanismus, (Erankfurt, 1949).

12 'See The Question Concerning Technology, ed. and trans. W. Lovitt, (New York, 1977), which contains some of Heidegger's most penetrating essays concerning the relationship between subjectivism, nihilism, and technology.

${ }^{13} \mathrm{M}$. Heldegger, Being and Time, p. 448. See D. C. Hoy, "History, Historicity, and Historiography in Being and Time," in Heldegger and Modern Philosophy. ed. $M$. Murry, (New Haven, 1978), pp. $\frac{329-53 .}{32}$

13 Ibid. , pp. 451-52.

1"F. Nietzsche, "The Use and Abuse of History," trans. A. Collins, (Indianapolis, 1949).

${ }^{133} \mathrm{M}$. Heidegger, Being and Time, pp. 442-44.

"Th, p. 15 .

${ }^{135}$ Ibid. , pp. $272-73$.

136 Ibid. , p. 324.

227 "Replik," (loc. cit.), p. 316.

13"Hermeneutics and Social Science," (loc. cit.), p. 314 .

${ }^{13}$ TM, pp. $265-66$.

160"On the Scope and Function," (loc. cit.), p. 21.

14'Ibid., p. 37 .

142 See Bubner, (10c. cit.).

14'See Ricoeur (loc. cit. 1982).

1"For an analysis of this probiem see my essay, "The Possibility of a Communicative Ethic Reconsidered: Habermas, Gadamer, and Bourdieu on Discourse," in Man and World 15, 1982. 
${ }^{145}$ TKH, Bd.I pp. 109-13 and Bd.II pp. 164-69; also Habermas: Critical Debates, ed. B. Thompson and D. Held, "A Reply to my Critics," pp. 261-63. 